\title{
Scenario-based assessment of buildings' damage and population exposure due to earthquake-induced tsunamis for the town of Alexandria, Egypt
}

\author{
G. Pagnoni, A. Armigliato, and S. Tinti \\ Sector of Geophysics, Department of Physics and Astronomy (DIFA), University of Bologna, Bologna, Italy \\ Correspondence to: G. Pagnoni (gianluca.pagnoni3@unibo.it)
}

Received: 23 July 2015 - Published in Nat. Hazards Earth Syst. Sci. Discuss.: 27 August 2015

Revised: 1 December 2015 - Accepted: 3 December 2015 - Published: 17 December 2015

\begin{abstract}
Alexandria is the second biggest city in Egypt with regards to population, is a key economic area in northern Africa and has very important tourist activity. Historical records indicate that it was severely affected by a number of tsunami events. In this work we assess the tsunami hazard by running numerical simulations of tsunami impact in Alexandria through the worst-case credible tsunami scenario analysis (WCTSA). We identify three main seismic sources: the western Hellenic Arc (WHA - reference event AD 365, $M_{\mathrm{w}}=8.5$ ), the eastern Hellenic Arc (EHA - reference event $1303, M_{\mathrm{w}}=8.0$ ) and the Cyprus Arc (CA - hypothetical scenario earthquake with $M_{\mathrm{w}}=8.0$ ), inferred from the tectonic setting and from historical tsunami catalogues. All numerical simulations are carried out in two sea level conditions (mean sea level and maximum high-tide sea level) by means of the code UBO-TSUFD, developed and maintained by the Tsunami Research Team of the University of Bologna. Relevant tsunami metrics are computed for each scenario and then used to build aggregated fields such as the maximum flood depth and the maximum inundation area. We find that the case that produces the most relevant flooding in Alexandria is the EHA scenario, with wave heights up to $4 \mathrm{~m}$. The aggregate fields are used for a building vulnerability assessment according to a methodology developed in the framework of the EU-FP6 project SCHEMA and further refined in this study, based on the adoption of a suitable building damage matrix and on water inundation depth. It is found that in the districts of El Dekhila and Al Amriyah, to the southwest of the port of Dekhila, over 12000 (13400 in the case of maximum high tide) buildings could be affected and hundreds of them could sustain damaging consequences, ranging from critical damage to total collapse. It is also found that in
\end{abstract}

the same districts tsunami inundation covers an area of about $15 \mathrm{~km}^{2}$, resulting in more than 150000 (165000 in the case of maximum high tide) residents being exposed.

\section{Introduction}

The main objective of this study is to assess Alexandria, Egypt, in terms of damage due to tsunami inundation, as well as the number of affected population. In the paper we focus our attention on tsunamis induced by earthquakes that constitute the major threat for the town, and we adopt an approach based on tsunami scenarios. Alexandria is one of the oldest cities in the world, founded in $331 \mathrm{BC}$ by Alexander the Great and close to the Egyptian port of Rakotis that was already known in Homeric times, and remained the capital of Egypt for over 1000 years. Administratively, Alexandria governorate consists of one large town, i.e. Alexandria, with about 4.1 million people, and two small cities, namely Borg El Arab and New Borg El Arab, together forming the metropolis, Alexandria. The governorate of Alexandria has a population of about 4.8 million. Today, Alexandria is a major city in the Mediterranean Sea, developing along a narrow strip of coast about $70 \mathrm{~km}$ long, separating the Mediterranean Sea from the inland Lake Maryut (its ancient name being Mareotis) that has an area of $75 \mathrm{~km}^{2}$. The city of Alexandria is considered to be Egypt's second capital by virtue of its location and population size. During summer months, the city receives some 3 million visitors (it was a mere 309000 in 2002), making it the most popular summer resort for Egyptians. The total area of Alexandria is 
$2680 \mathrm{~km}^{2}$, divided into six districts that from NE to SW are as follows (see Fig. 1): Al-Montazah, Sharq (eastern Alexandria), Al-Gomrok, which is the historic old town, Wassat (central Alexandria), El-Dekhila-Agami (western Alexandria) and Al-Amriyah, the first five situated on the coast, and the latter located further inland.

Alexandria plays a key role in the national economy: the port of Alexandria is Egypt's largest, with $57 \%$ of the total port capacity in the country, and it is a major port in the Mediterranean Basin. In the paper (Fig. 1) we will denote the Ras el-Tin harbour, which is mainly used for yachting and fishing boats and is not navigable by large vessels, as the eastern port of Alexandria. This is the place where the ancient Great Harbour of Alexandria was located, as testified by submerged port structure remains identified by archeologists. The harbour is protected by a breakwater system with an average height of $3 \mathrm{~m}$ a.s.l., leaving two entrances of $\sim 240 \mathrm{~m}$ (west) and $\sim 140 \mathrm{~m}$ (east) width. Further, the harbour basin between Ras el-Tin and Wassat will be considered as formed by two ports, denoted as the port of Dekhila to the west and the western port of Alexandria to the east, which is the most important port of the region. The port of Dekhila defence system is formed by two joint breakwaters, one parallel to the coast about $2250 \mathrm{~m}$ long and the other, more recently constructed, $\sim 600 \mathrm{~m}$ long, with an average height of 4 and $1.5 \mathrm{~m}$ a.s.l. in the head zone. Notice that the eastern and western ports of Alexandria are separated by a tombolo, i.e. by a narrow strip of land or isthmus, connecting the mainland with the former island of Pharos, that today forms a Tshaped peninsula. From its western end, a $2400 \mathrm{~m}$ long and shallow ( $\sim 2 \mathrm{~m}$ a.s.l.) breakwater, in an almost $\mathrm{N}-\mathrm{S}$ direction, leaves an entrance of about $400 \mathrm{~m}$ for ship traffic. Close to the harbour area one can also find one of the most important industrial districts in Egypt, with several large, well-equipped industrial plants (e.g. Borg El Arab, Merghem, Om Zegheow and El Gharbaneyyat) that give it a dominant position in the manufacturing sector. Other industrial sectors are very important: chemical and petrochemical, steel, iron and engineering, construction materials, wood products, food, etc.

From a physiographic point of view, the city of Alexandria lies on a series of narrow Late Pleistocene ridges running parallel to the coast separating the sea from the very shallow Lake Maryut, which is one of the many lagoons and marshes characterizing the vast area of the Nile Delta. These brackish lakes are connected to the sea by a complex system of artificial waterways, two of which, the Alexandria and the Al-Max channels, drain the waters of the Lake Maryut into the Alexandria harbour basin also by means of pumping stations, between the port of Dekhila and the western port of Alexandria in the district of Wassat.

Alexandria has been hit by a number of tsunamis in the course of history (see Papadopoulos et al., 2007; Salamon et al., 2007), two of which have flooded the city with destructive effects, namely the 21 July AD 365 and the 8 August 1303 Crete tsunami events. The detailed reconstruction of these

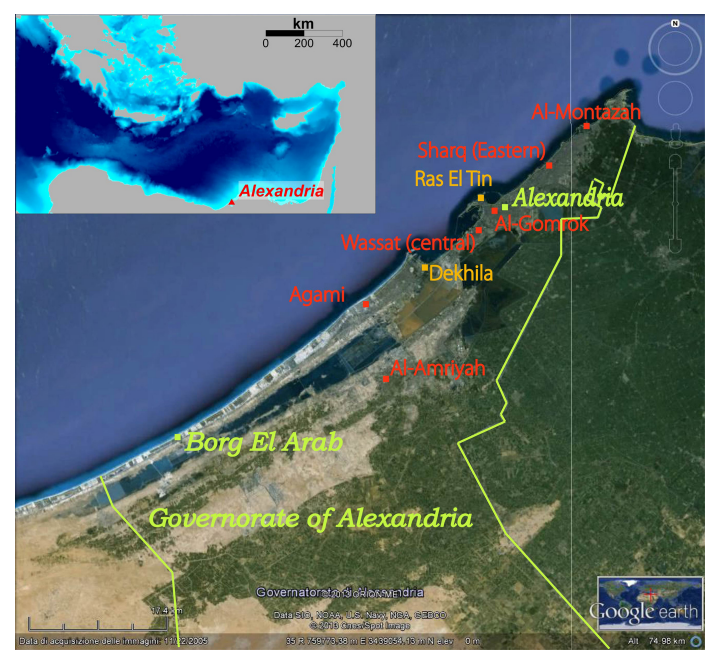

Figure 1. Governorate of Alexandria. Names of the districts are in red. Places that are affected by major inundations according to the computations of the paper are in orange. In the upper left corner there is a map of the eastern Mediterranean which includes Alexandria.

tsunamis is outside of the scope of this paper. We will only recall their most relevant features in the following.

\subsection{The AD 365 tsunami}

The AD 365 earthquake and tsunami were first described by coeval sources. Ammianus Marcellinus (see Guidoboni et al., 1994; Stiros, 2001), a Roman historian who lived in the fourth century (AD 325-391), wrote in AD 378, which is 13 years after the event's occurrence, that the earth was shaken by an earthquake and then a tsunami brought destruction to ships in the sea and to people on land. He speaks of a strong sea withdrawal and return, of several thousands of people who drowned, mainly because they were surprised by the unexpected return of the water. He spoke of vessels which had landed on roofs, and of some other vessels which had been carried inland, more than 2 miles from the coastline. Indeed, Ammianus Marcellinus does not refer all the above occurrences to any specific geographical locations, apart from two exceptions. (1) He mentions Alexandria when he speaks of ships that were left on house roofs (“... Ingentes aliae naves, extrusae rabidis flatibus culminibus insedere tectorum, ut Alexandriae contigit, ..." "Other big vessels pushed out of the sea by the fury of winds ended on the top of roofs, which occurred in Alexandria ...") and (2) he mentions Methoni, a town in Messenia, southern Peloponnese, Greece, when he reports about ships that had been transported about 2 miles inland (“... ad secundum lapidem fere procul a litore contortce sunt aliqua, ut Laconicam prope Mothonem oppidum nos transeundo conspeximus, diuturna carie fatiscentem ..." "Some vessels were carried up to 2 miles away from the coast, as I saw one from Sparta dilapidated from long 
decay while I was travelling near the town of Methoni”.). Therefore, his description, although quite realistic, cannot be used for a modern reconstruction. From later sources it seems that most of Alexandria escaped destruction and that damage was confined to the narrow causeway connecting the town to the island of Pharos, where the famous lighthouse, one of the seven wonders of the world, was built (Shaw et al., 2008; Stiros, 2010). It was called "Eptastadion" (PararasCarayannis, 2011) since its length was about 7 stadia (a stadium is an ancient Greek distance unit equal to $184.45 \mathrm{~m}$ ) and the tombolo that formed on it today divides the east from the west port of Alexandria in the district of Al-Gomrok (see the locality Ras el Tin in Fig. 1). Recent studies agree that the AD 365 shock was a large-magnitude $\left(M_{\mathrm{w}}=8.3-8.5\right)$ earthquake that occurred in the Hellenic subduction zone between south-western Crete and the Peloponnese (e.g. Stiros, 2010). Uplifts of up to $10 \mathrm{~m}$ on the coast of western Crete were recognized, identified and dated (Pirazzoli et al., 1992, 1996; Shaw et al., 2008) and, as for today, are the main clue to placing the source of this tsunami in the western Hellenic Arc (WHA). In this study an AD 365-like tsunami is one of the worst-case credible scenarios we use to evaluate the tsunami vulnerability of Alexandria.

\subsection{The 1303 tsunami}

The 8 August 1303 earthquake was destructive over a vast area of the eastern Mediterranean and the ensuing tsunami also caused a widespread damage in many countries, including Egypt. According to several studies, that also consider Arab documentary sources (e.g. Ambraseys et al., 1994; Guidoboni and Comastri, 1997, 2005; El Sayed et al., 2000), the most severe earthquake destruction was suffered by Candia (Heraklion today), Crete; but also Peloponnese towns were affected. Intense damage was reported in Cyprus, Palestine (city of Safad) and also in Egypt where Cairo and Alexandria were severely hit. In Alexandria, the city walls and the lighthouse partially collapsed and many houses were ruined. The area of the reported damage was so large that some were led to doubt that it was a unique event and it was hypothesized that historical accounts show the collective effects of a series of earthquakes which occurred in different seismic zones. There is a general consensus that the earthquake (or the bigger earthquake in the case of a multiple source scenario) occurred in the eastern Hellenic Arc (EHA) with an $M_{\mathrm{w}}$ of around 8.0 (Papadopoulos et al., 2014).

Effects of the tsunami are reported in several coeval sources with explicit reference to the towns of Candia (Heraklion), Crete, in Italian sources, and of Acre (Israel), Alexandria and Nile in Arab sources. In Alexandria, vessels broke moorings in the harbour and crashed against rocks. The tsunami reached the town walls and many shops and warehouses were flooded and destroyed (Ambraseys, 1962; Antonopoulos, 1980; Guidoboni and Comastri, 1997; El
Sayed et al., 2000; Papadopoulos et al., 2007; Papadopoulos, 2011).

In this study, a 1303-like tsunami whose source was in the EHA is considered as one of the worst-case credible tsunami scenarios.

\section{The worst-case credible tsunami scenario analysis (WCTSA)}

Tsunami scenarios are used as a tool to plan the immediate response of coastal communities to a tsunami attack by emergency managers in the context of tsunami early warning systems, as well as to carry out hazard, vulnerability and risk analyses in the framework of long-term mitigation policy planning. In this latter case, scenario-based techniques are often seen as a means that is alternative or complementary to probabilistic approaches. A typical product of a probabilistic tsunami hazard analysis (PTHA) is the inundation area or the maximum sea surface elevation that is expected in a given place (stretch of coastline, port, beach, etc.) in a given return period, say 100 or 500 years. The method is essentially mimicked from the probabilistic analysis applied to earthquakes and was first suggested in the early 1980s by Lin and Tung (1982). The concept was independently developed and applied to evaluate the maximum expected wave at the coast in the Italian seas by Tinti (1991a, b) and in Morocco by El Alami and Tinti (1991), but it is only in more recent times that it has been fully developed, discussed and extensively applied (see e.g. Geist and Parsons, 2006; Burbidge et al., 2008; Lorito et al., 2008, 2015; Gonzalez at al., 2009; Sørensen et al., 2012; Leonard et al., 2014; Brizuela et al., 2014). The main drawback of this method is that it relies upon the occurrence probability distribution function of the tsunamigenic sources, which cannot always be estimated reliably, especially if submarine mass failures are involved. Therefore, it is often restricted to application where only tsunamis of seismic origin are taken into account, with only rare exceptions (see Grilli et al., 2009).

The scenario-based approach stands on the idea that in many applications concerning tsunami mitigation, what matters most is not the knowledge of the effects of a full spectrum of tsunami events with associated probability of occurrence, but only the knowledge of the features of the extreme events. Typically in a given coastal place, one wants to assess the most extended inundation area due to tsunamis, the maximum tsunami height, etc. In principle, one could derive this information from a PTHA by considering longer and longer return times, but it is more practical to avoid all the probability assessment complications and consider only the largest sources and therefore the largest produced tsunamis. The main steps of the scenario-based hazard analysis can be summarized as follows: (1) identification and characterization of the sources (earthquakes, volcanos, landslides) capable of producing the largest tsunamis for a given target 
Table 1. Fault parameters for the three scenarios analysed in the paper.

\begin{tabular}{llll}
\hline Fault & WHA & EHA & CA \\
\hline Length $(\mathrm{km})$ & 130 & 100 & 100 \\
Width $(\mathrm{km})$ & 86 & 46.7 & 46.7 \\
Strike & $314^{\circ}$ & $236^{\circ}$ & $280^{\circ}$ \\
Dip & $35^{\circ}$ & $20^{\circ}$ & $20^{\circ}$ \\
Rake & $90^{\circ}$ & $90^{\circ}$ & $90^{\circ}$ \\
Slip $(\mathrm{m})$ & 17.5 & 8.0 & 8.0 \\
Upper edge depth $(\mathrm{km})$ & 5 & 5 & 5 \\
\hline
\end{tabular}

location, (2) simulation of the tsunamis and computation of the desired metrics in the target place and (3) computation of the local aggregate (envelope) scenario by combining all the individual scenarios. This method can be called the method of the probable maximum tsunami (PMT) (see Grilli et al., 2011) or equivalently, the worst-case credible tsunami (WCT) method (see Tonini et al. 2011). It is noted that the specifications "probable" and "credible" in these locutions means (i) that the scenarios considered are reasonably grounded on scientific acceptable assumptions (e.g. the maximum possible earthquake size of a given seismic zone) and (ii) that very improbable scenarios are ruled out (e.g. the impact of a meteorite or asteroid in the sea just off the target place), which is a possible catastrophic case, but with an extremely low probability of occurrence.

The above steps lead to the computation of an envelope or aggregate scenario in a given place that forms the basis for subsequent studies. In particular, in this paper we estimate the maximum area of inundation for the governorate of Alexandria and then we evaluate the exposure, vulnerability and damage of the buildings in the residential area and the number of affected people.

\section{The selected tsunamigenic sources}

Seismotectonics focussed on tsunami activity and potential in the eastern Mediterranean has been the subject of several recent works with regional and also local focus (see Soloviev et al., 2000; Tinti et al., 2005; Fokaefs and Papadopoulos, 2007; Papadopoulos et al., 2007; Salamon et al., 2007; Lorito et al., 2008; Ebeling et al., 2012; Sørensen et al., 2012; Yolsal-Çevikbilen and Taymaz, 2012). Most of these works were mainly concentrated on tsunamis generated by earthquakes; but also tsunamis due to landslides are of some relevance in the region. Indeed, it is known (Fokaefs and $\mathrm{Pa}-$ padopoulos, 2007; Salamon et al., 2007; Papadopoulos et al., 2014) that tsunamis that occurred off Syria, Lebanon, Israel and Palestine, and that are associated with earthquakes in the Dead Sea Transform fault, have been attributed to submarine sediment failures triggered by seismic load rather than to the sea floor deformation caused by earthquakes (since faults

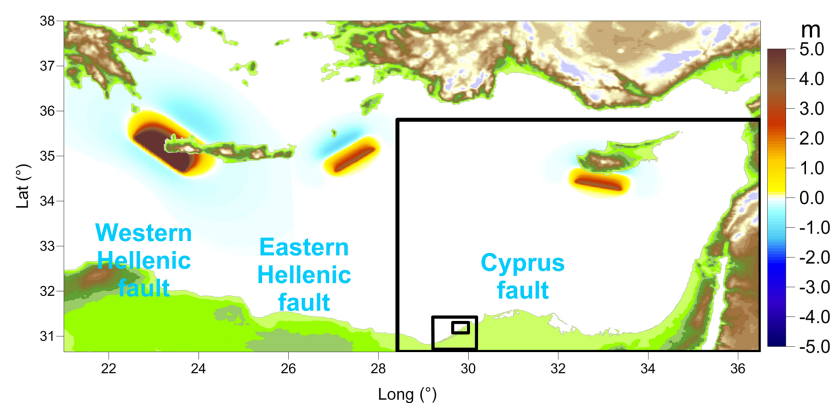

Figure 2. Initial sea surface elevation for the three tsunami scenarios treated in the paper. Tsunami simulations are carried out in four grids: the outer grid (grid 1) coincides with the map shown here, while the three black boxes show the boundaries of the three nested grids (grid 2 to 4). Grid 4, centred on Alexandria, has two different topo-bathymetric data: one for the mean-sea-level tsunami simulations and one for the maximum high-tide tsunami simulations, which differ by the uniform static value of $30 \mathrm{~cm}$.

are too far from the sea and with mechanisms unfavourable to tsunamigenesis). Numerical simulations of tsunamis induced by these submarine mass failures (see the tsunami following a $1.25 \mathrm{~km}^{3}$ volume collapse in the Akhziv submarine canyon, $30 \mathrm{~km}$ north of Haifa in Salamon et al., 2007) show that their effects may be disastrous near the source, but are minor further afield. For this main reason, in the present study we only focus our attention on scenarios of tsunamis caused by earthquakes. It is worth mentioning here also the work by Garziglia et al. (2007) who studied a huge masstransport deposit, of about $14 \mathrm{~km}^{3}$, called S16 that was triggered during the Holocene sea-level rise circa $10 \mathrm{kyr}$ BP in the western Nile margin in a phase of exceptional river sediment supply. Consequently, they simulated a tsunami with a source only some $50 \mathrm{~km}$ north of Alexandria. The numerical simulations show that waves with a height of $4 \mathrm{~m}$ can attack the coast (Garziglia et al., 2007). However, our evaluation is that the mass transport was probably too slow to generate a tsunami and that even accepting that it was tsunamigenic, it is a scenario far less probable to occur today than scenarios of tsunamis of seismic origin. Therefore, in the following we do not take it into account.

Considering all the main tsunamigenic seismic zones of the Mediterranean, Sørensen et al. (2012) were able to show that the sources that are most influential for the area of Alexandria are essentially the EHA and the WHA. Following their suggestion, and on the basis of the tsunami history, showing that the largest tsunamis known to have hit the town were due to the AD 365 earthquake in the WHA and to the 1303 earthquake in the EHA, we selected two scenarios with faults represented in Fig. 2 and with geometry and focal mechanism given in Table 1 . The magnitudes of the scenario earthquakes are compatible with the ones taken by Sørensen et al. (2012). In more detail, the selected WHA source coincides with the fault introduced by Lorito et al. (2008), char- 
acterized by an $M_{\mathrm{w}}$ of 8.5. The geometry of the EHA source is borrowed from the paper by Yolsal-Çevikbilen and Taymaz (2012), but the position of the fault is chosen in order to maximize the tsunami propagation effect towards Alexandria.

In addition to the above cases, we also explore a third scenario, that is a tsunami of seismic origin from a fault in the Cyprus Arc (CA). The reason is that this zone is known to be tsunamigenic (Fokaefs and Papadopoulos, 2007) and known to be susceptible to large-magnitude earthquakes. We assume a $M_{\mathrm{w}}=8.0$ earthquake, not far from the assumption made by Salamon et al. (2007) who state $M_{\mathrm{w}}=7.8$, while Sørensen et al. (2012) and Papadopoulos et al. (2014) estimate a maximum magnitude for this area of $M_{\mathrm{w}}=7.5$. Further, the position and strike of the fault in the present study (see Fig. 2 and Table 1) is selected in such a way to maximize tsunami effects on the Egypt coasts, while a similar case treated by Salamon et al. (2007) was assumed in a different location along the arc, with a strike more likely to direct most of the tsunami energy towards Israel.

\section{Tsunami simulations}

Tsunami simulations have been conducted by using the code UBO-TSUFD that solves shallow-water non-linear equations with dynamic boundary conditions and a finite difference technique, where the unknowns are the sea surface elevation with respect to the still sea level and the two horizontal fluxes or discharges, i.e. the product of the sea surface elevation by the particle horizontal velocity components (Tinti and Tonini, 2013). The initial conditions for the tsunami scenarios are computed by means of the analytical Okada's formulas for the static deformation of an elastic half-space induced by a uniform co-seismic slip on a rectangular fault (Okada, 1992). The hypothesis is that the sea floor vertical displacement is transferred instantaneously and unchanged to the sea surface, which can be considered a quite acceptable assumption. The complementary hypothesis is that the initial horizontal velocity is identically zero. Both such conditions are usual for tsunami simulations, unless more precise knowledge of the rupture process (e.g. dynamic rupture pattern, heterogeneous slip distribution) is obtained from additional data. Pure transparency is imposed on the open boundaries allowing the tsunami waves to go across the grid limits with no spurious back reflection, while on the coast an algorithm based on extrapolating the seaside wave profile landward determines if a cell is wet or dry, and the shoreline position is computed dynamically (Tinti and Tonini, 2013).

To ensure that the model computes the tsunami interaction with the irregular coast in the target place (i.e. Alexandria) adequately and at the same time to optimize computer resources, the strategy of nested grids is adopted by the code UBO-TSUFD with full coupling between the outer (coarser) and the inner (finer) grid. Usually, the finer grid is totally contained within the outer grid, and this is the case for the scenarios treated in this paper, but this is not a requirement of the code. Notice that in the area of overlapping that is common to both grids, computations are only carried out in the finer grid. Technically, if we consider a multilevel nesting with level $N+1$ grids nested in the grid of level $N$, the computation domain of the level $N$ grid is the one obtained as the difference between the area covered by the grid and the area that is the union of all grids at level $N+1$. In total, the grid system in this work is formed by four grids, from level 1 to level 4, that are shown in Fig. 2. The external grid, at level 1, covers all the eastern Mediterranean Sea with a $3 \mathrm{~km}$ resolution and is large enough to contain the faults of all tsunami scenarios as well as the respective tsunami initial conditions. Since the deformation produced by Okada's equations decreases quite slowly with the distance from the fault (which results in an initial tsunami source virtually extending up to infinity), sea elevations with magnitudes less than $5 \mathrm{~cm}$ have been put equal to zero, and a proper tapering window has been used to avoid discontinuities. The modified initial fields are given in Fig. 2. The second grid, grid 2, covers the south-eastern part of the Levantine Sea with a $1 \mathrm{~km}$ resolution. Grid 3 (200 $\mathrm{m}$ resolution) and grid 4 (40 m resolution) cover a much smaller area and are centred respectively on the governorate of Alexandria and on the city of Alexandria, which is the study area in this paper.

The topo-bathymetric data sets used to build the grids are listed in Table 2. Grids 1 and 2 were built basically using the General Bathymetric Chart of the Oceans (GEBCO) (30 arcsec) and the Shuttle Radar Topography Mission (SRTM) ( 90 m) databases. The local grids 3 and 4 were integrated with bathymetry data in UTM coordinates from nautical charts (1:5000 and $1: 10000)$, and also from the work by El-Geziry et al. (2007) for the western port of Alexandria; while SRTM topography was cross-checked with Google Earth data at selected control points. Specific attention was given to reconstructing the shoreline position and the shape of breakwaters and jetties in the ports of Alexandria and Dekhila by making use of Google Earth images. It is worth mentioning that the bathymetry of the different grids has to be harmonized along and in the area around the common boundaries, especially in near-shore regions to avoid artificial depth discontinuities that might give rise to irregular wave behaviour and even result in numerical instabilities.

All simulations were carried out for two different sea-level conditions: mean sea level and the maximum high-tide level. The tidal range in the Alexandria is about $60 \mathrm{~cm}$ (see the analysis by El-Geziry and Radwan (2012), who examined the 1996-2005 decade records of the western port tide-gage). Accordingly, we assume in the paper that the highest hightide sea level exceeds the mean sea level by $30 \mathrm{~cm}$. The maximum high-tide bathymetry and topography were obtained by lowering the depth of the sea floor and the altitude of the dry land in the local grid 4, centred on the Alexandria coast and ports, by $30 \mathrm{~cm}$. The assumption is that tides are 
Table 2. Topo-bathymetric data sets used to build grids 1 to 4 for tsunami simulations.

\begin{tabular}{llll}
\hline Name & Type & Resolution & $\begin{array}{l}\text { Coordinate } \\
\text { system }\end{array}$ \\
\hline GEBCO & Raster topo-bathymetric & 30 arcsec & Geographical \\
\hline SRTM & Raster topographic & $\sim 90 \mathrm{~m}$ & Geographical \\
\hline $\begin{array}{l}\text { Digitized nautical } \\
\text { chart }\end{array}$ & $\begin{array}{l}\text { Bathymetric contour } \\
\text { lines and scattered points }\end{array}$ & $\begin{array}{l}1: 5000 \\
1: 10000\end{array}$ & UTM \\
\hline $\begin{array}{l}\text { Digitized from El- } \\
\text { Geziry et al. (2007) }\end{array}$ & $\begin{array}{l}\text { Bathymetric contour } \\
\text { lines and scattered points }\end{array}$ & $\sim 20 \mathrm{~m}$ & UTM \\
\hline $\begin{array}{l}\text { Google Earth } \\
\text { topography }\end{array}$ & Transects & $\begin{array}{l}\text { Control } \\
\text { points }\end{array}$ & Geographical \\
\hline
\end{tabular}

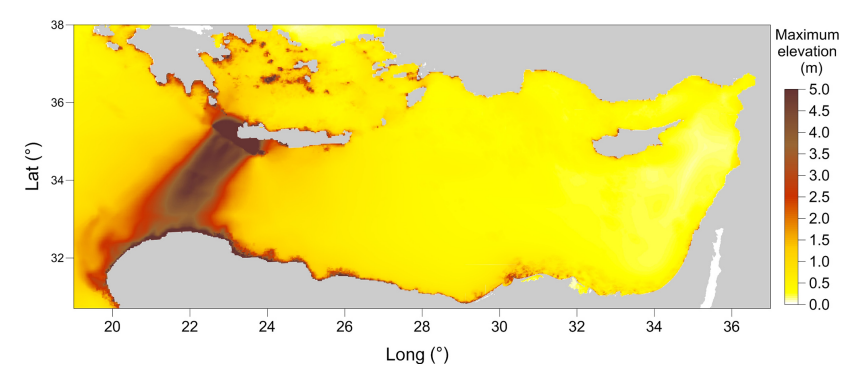

Figure 3. Sea surface maxima in grid 1 for the tsunami generated by the western Hellenic Arc (WHA) earthquake (see Table 1 for details).

not relevant for tsunami propagation offshore, but only in the nearshore region. All the results shown in detail in the following sections refer to the mean-sea-level condition, while results for the maximum high-tide level are summarized in the Appendix A2.

\subsection{The WHA tsunami}

The WHA earthquake caused a tsunami that focussed most of its energy towards the Libyan coasts and SW-ward (see Fig. 3), though only a marginal part of the waves travel towards the eastern Mediterranean. Sea level maxima in the local grid 3 shown in Fig. 4 are above $2.5 \mathrm{~m}$ along almost the entire Alexandria governorate coastline, with peaks above $4 \mathrm{~m}$ in correspondence with the Borg El Arab area, possibly related to local bathymetric features. Note that we have made reference to the grid number only for the sake of simplicity. To be more precise, when we show the fields in the region of computation covered by the grid of level $N$, we also show the fields calculated in all the nested grids at levels larger than $N$ at the same time. The fact that there is perfect continuity between fields across the grid boundaries as it appears from Figs. 3 and 4 is a demonstration of the good performance of the code UBO-TSUFD. The same comment applies to all other figures of the paper where tsunami fields are represented. Propagation fields depicted in Fig. 5 at intervals of 20 min for the first 140 min show the main front travelling quickly towards the south of the central Mediterranean Basin. The last four panels of Fig. 5 show the propagation in the Levantine Sea over grid 2. The tsunami advances with a leading negative wave attacking Cyprus in the north and Alexandria in the south about $80 \mathrm{~min}$ after the earthquake. Notice the strong bending of the southern part of the front to the east of Alexandria due to refraction, with the result that the tsunami front tends to align with the depth isolines and attacks the coast at a normal angle (see the bottom panels of Fig. 5). The tsunami floods the beaches to the west of Alexandria, the port of Dekhila and the Wassat area, as well as the harbour facilities of the western port of Alexandria (Fig. 6). The flooding is less evident for the eastern port. In the areas where the inundation distance is larger, flow depth can exceed $2.0-2.5 \mathrm{~m}$. Notice that the WHA scenario tsunami does not flood the tombolo between the eastern and western ports of Alexandria, which was probably inundated by the AD 365 event. This is not, however, a serious drawback of the scenario, since the topography today is probably not the same as at the time of the historical tsunami. What is confirmed is that the tsunami is damaging, although not disastrous, for Alexandria.

\subsection{The EHA tsunami}

The EHA tsunami directs the bulk of its energy towards Alexandria (see Fig. 7). This is mainly due to the assumed strike of the fault, and is a well-known feature of essentially 2 -D wave processes originating from long linear sources. The beam of sea level maxima is orthogonal to the fault and is strong along the entire path from the source to the Alexandria coasts where they amplify. The zoom on the area of Alexandria (see grid 3 represented in Fig. 8) shows that maxima may exceed $2 \mathrm{~m}$ offshore and that tsunami causes extended inundation all along the town coast from SW to NE. The propagating front is shown in the snapshots of Fig. 9. From panels at 20 and $40 \mathrm{~min}$ it is clear that the tsunami travels 


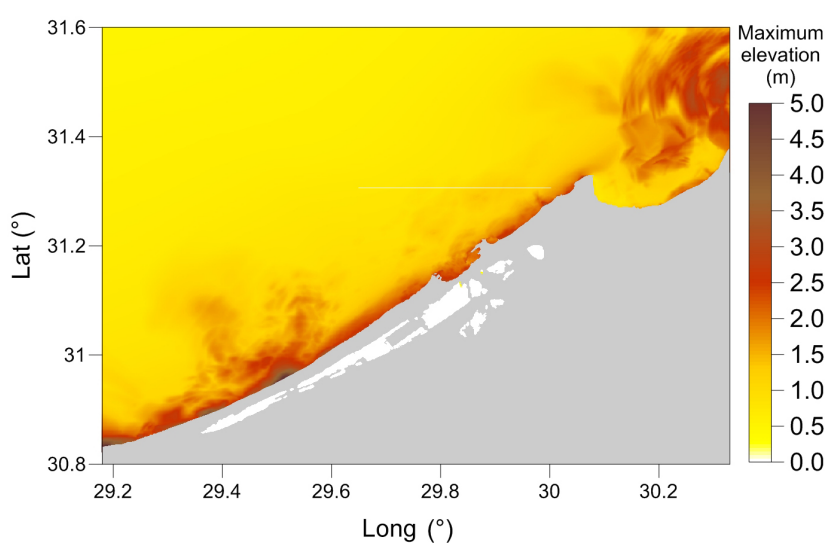

Figure 4. Sea surface maxima for the WHA source, zoomed in on the area of Alexandria with grid 3 (200 m resolution).

with a leading positive wave towards Alexandria. The panel at $1 \mathrm{~h}$ shows the strong interaction of the tsunami with the continental margin, causing the strong bending of the front and the remarkable shortening of the wavelength (with crests and troughs coming closer to each other). The snapshot at $1 \mathrm{~h}$ 20 min shows that the front is very strong not only in Alexandria, but even in the whole region to the east of the town, that indeed is only covered by the $1 \mathrm{~km}$ resolution grid 2 . The inundation in the town of Alexandria is depicted in Fig. 10 (grid 4). It is seen that most of the coast is flooded and in some zones, the tsunami penetrates a few kilometres deep in the interior beyond the coastal ridge. Flooding in the area of the old port of Alexandria (Ras el-Tin) is noticeable, but not dramatic; the outer breakwaters of both the eastern and western ports of Alexandria are overtopped and the harbour facilities, together with the waterfront buildings, are inundated. This is compatible with the effects reported for the 1303 tsunami mentioned in one of the previous sections.

\subsection{The CA tsunami}

The source located in the CA is selected on purpose in a position of the arc, such that it launches most of the tsunami energy towards the Egyptian coast. The pattern of the sea surface elevation maxima (Fig. 11) displays the effect of the Eratosthenes Seamount, a $\sim 2000 \mathrm{~m}$ high massif south of the fault, that amplifies the tsunami and concentrates it against the eastern part of the Nile Delta, where extensive flooding is computed in the area of Damietta and Port Said (grid 2), quite far from Alexandria. In the shelf off Egypt the structure of the maxima is complex and one can observe amplified branches even on the western part of the Nile Delta just to the east of Alexandria. In the large Alexandria region, however, the tsunami extreme elevations are only in the range of 1.0-1.5 m near the coast (Fig. 12). The tsunami propagation frames shown in Fig. 13 display a concentration and splitting of the tsunami front (a leading positive wave) induced by the Eratosthenes massif that attacks the Egypt coast with a long double crest system (see tsunami elevation fields taken at $1 \mathrm{~h}$ and following times). Figure 14 shows that flooding in Alexandria is somewhat less pronounced than for the WHA and the EHA scenarios; the largest effects are observed in the Dekhila port area.

The simulation shows that CA tsunami scenario foresees moderate flooding in Alexandria and severe flooding in the eastern part of the Nile Delta. Going through tsunami catalogues and specialized literature, one can find mention of a few tsunamis flooding this area. The most interesting for our study is the tsunami associated with an earthquake that occurred between 26 and $17 \mathrm{BC}$ and caused severe damage in Paphos, Cyprus (Guidoboni et al., 1994). The earthquake generated a tsunami that hit Cyprus, but also the town of Pelusium on the eastern side of the Nile Delta according to some studies (Altinok and Ersoy, 2000; Fokaefs and Papadopoulos, 2007; Altinok et al., 2011), or the entire coast from Alexandria to Pelusium, according to others (Ambraseys, 1962). Considering that Pelusium was one of the most important towns of Lower Egypt that was located to the east of present-day Port Said, one can see that the inundation associated with the CA tsunami scenario seems reasonably consistent with the historical data.

\subsection{Virtual tide gauges}

Time histories of the sea surface elevations calculated for some virtual tide gauges, i.e. computed in some nodes of the simulation grids, may help to understand the tsunami dynamics better. For this purpose we have selected four nodes in grid 4 (that has the highest resolution). Tide gauge 1 is placed some $15 \mathrm{~km}$ offshore and the others are placed very close to the coast in less than $10 \mathrm{~m}$ sea depth. Tide gauges 2 and 4 are in the open sea, to the east and west of Alexandria respectively, while tide gauge 3 is within the port of Dekhila. Their positions can be seen in Fig. 6 and are also reported in Figs. 10 and 14. The computed time series are displayed for all the scenarios in Fig. 15 for the first 300 min of tsunami propagation.

If one considers the tide gauge offshore (node 1), the largest waves are due to the EHA tsunami, that arrives in the shortest time and starts with an impulsive, positive front of more than $1 \mathrm{~m}$ amplitude. The first oscillation is strongly asymmetric and is followed by much weaker waves, with a dominant period of about $20 \mathrm{~min}$. From the propagation pattern portrayed in Fig. 9, we know that this is the signal of the main front attacking Alexandria. The WHA tsunami is second in size (about $1 \mathrm{~m}$ amplitude) and third in arrival time (about $40 \mathrm{~min}$ later). This is consistent with the propagation snapshots shown in Fig. 5, where we can recognize the arrival of a very weak negative front about 60 to $70 \mathrm{~min}$ after the earthquake occurrence, followed by a much stronger positive front at 80-90 min. Large amplitude oscillations are observed also after 140, 200 and $250 \mathrm{~min}$. The CA signal arrives 5 min after the EHA tsunami and is significantly weaker, and 

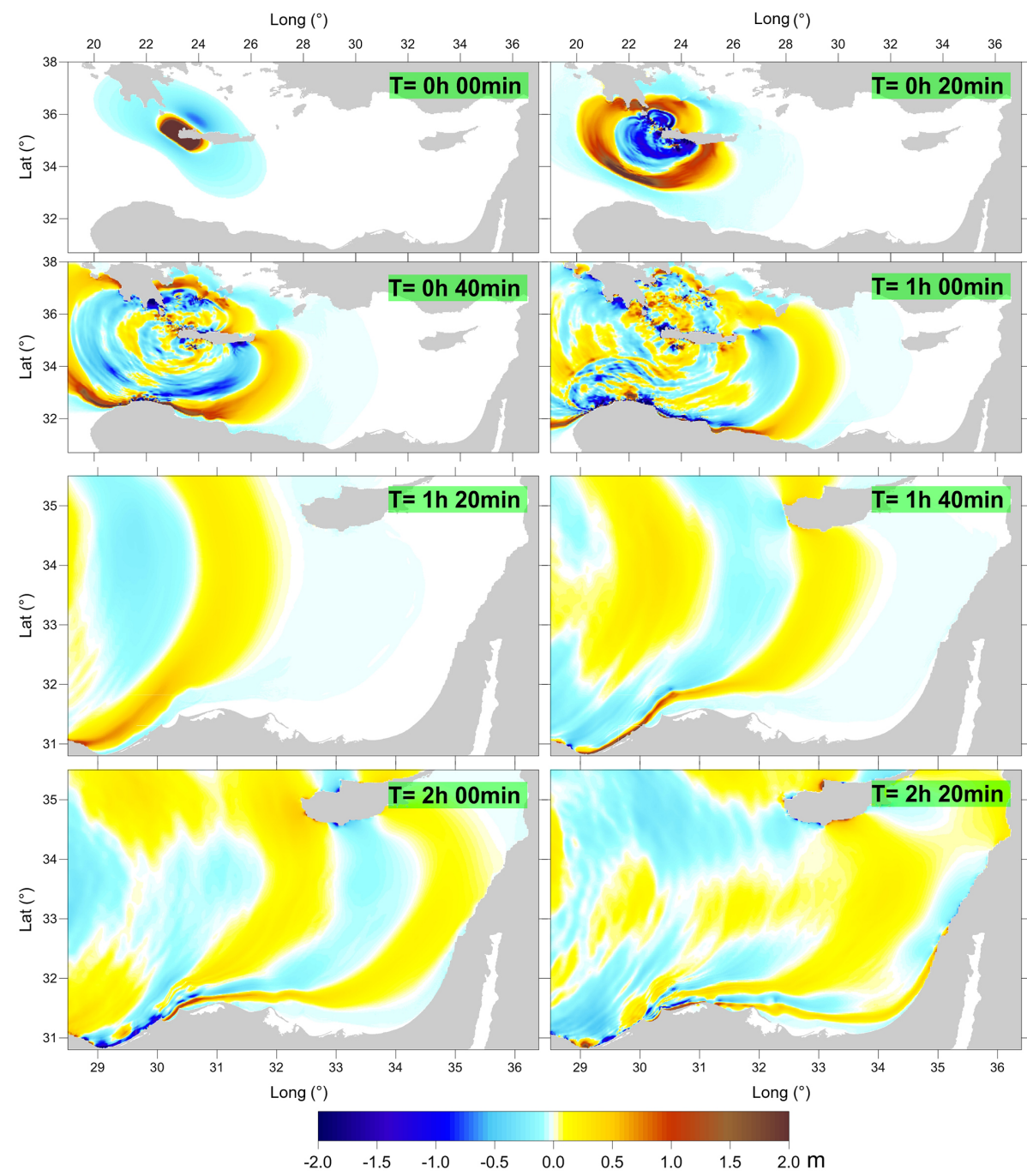

Figure 5. Propagation fields for the WHA tsunami scenario. Snapshots taken every $20 \mathrm{~min}$. Fields from $t=0$ to $t=1 \mathrm{~h}$ are plotted in grid 1 ; the other ones are plotted in grid 2.

all the following oscillations are irregular and of similar amplitude. Figure 13 indicates that this is the signature of the western side of the tsunami front that is refracted and loses energy while advancing towards the coast that here in the region of El Alamein, west of Alexandria, has an overall concave shape.

Looking at tide gauge 2, one observes that the ranking of the scenarios as regards the size and the arrival time is unchanged. Waves are remarkably amplified by a factor of 2 or more. Tide gauge 4 is the last virtual sensor facing the open sea; here EHA and WHA exhibit comparable maximum amplitudes, although at different arrival times. Moreover, EHA signal amplitude is reduced with respect to tide gauge 2, while comparable values are observed for WHA in the two virtual sensors; this was similarly observed for CA. The time histories of tide gauge 3 show the protecting effect of the harbour jetties and the interaction of the harbour with incoming waves of different wavelengths. The size of the EHA signal is smaller than for coastal tide gauges 2 and 4 . The signal, however, seems to be dominated by normal modes of the harbour basins more than by the source signature; the oscillations persist with little amplitude decrease for a longer time and seem to be "more periodic" with a period of about 30-35 min for all scenarios. These harbour basins' normal modes are even more evident in the time history relative to WHA; the amplitude is comparable to those observed in tide gauges 2 and 4 , and remains almost unchanged for more than $4 \mathrm{~h}$.

A further consideration is that the arrival times of tsunamis at the coastal tide gauges are in the order of 70-80 min and, in the case of an early warning, would allow people who are in danger to react and to evacuate, provided that evacuation plans are implemented. 


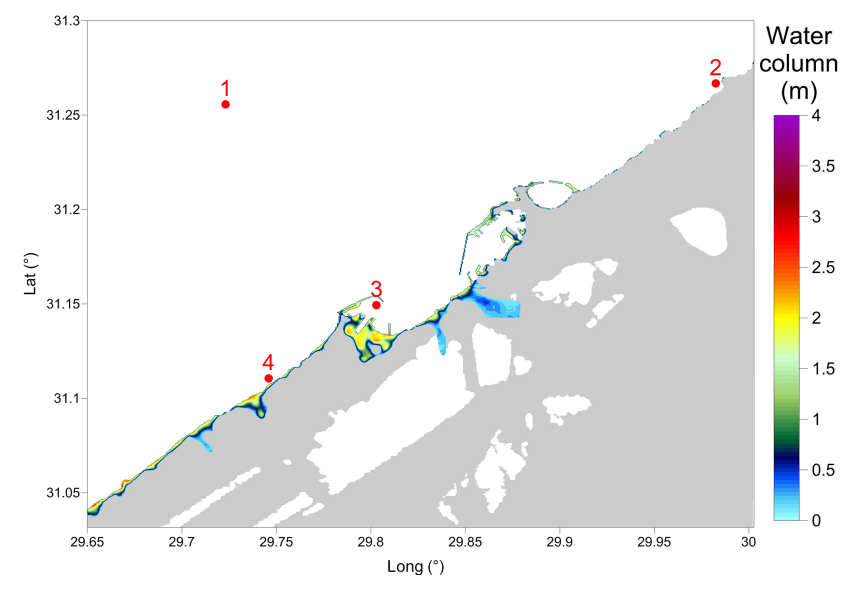

Figure 6. Water depth maxima on land for the WHA case plotted in grid 4 (40 m resolution) in mean-sea-level conditions. Red circles show the position of four virtual tide gauges: gauge 1, quite far offshore, and the other three, very close to the coast.

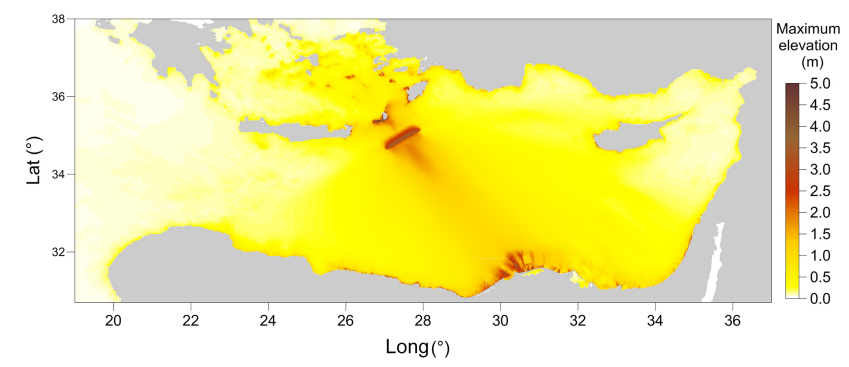

Figure 7. Sea surface maxima in grid 1 for the tsunami generated by the eastern Hellenic Arc (EHA) earthquake (see Table 1 for details).

\section{The aggregate scenario}

Building the aggregate scenario is the last step of the scenario-based tsunami hazard analysis. After selecting the appropriate tsunami metrics or parameters, one produces the aggregate fields by taking the envelope of the individual scenarios, which more precisely means selecting the extreme of the values of the individual scenarios for each point of the field. In this study a fundamental parameter is the depth of the water column in the inundated area that has been shown in Figs. 6, 10 and 14 for the respective WHA, EHA and CA cases. The corresponding envelope is shown in Fig. 16, which also gives the maximum inundation line superimposed on a Google Earth image, marking the boundary between the area that is not inundated by any one of the scenario tsunamis and areas that are inundated by at least one tsunami. It has to be remarked upon that in practice, the envelope is very similar to the EHA scenario, with the exception of the Dekhila port area, where WHA gives the predominant contribution. The identification of a single scenario with the aggregate one is not surprising, though it is not the rule; usually one finds a dominant scenario contributing to the aggregate much more

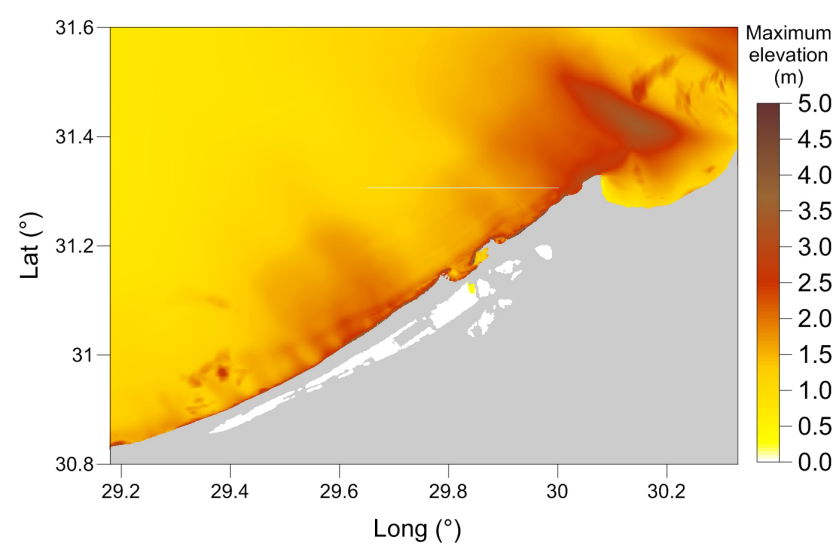

Figure 8. Sea surface maxima for the EHA source, zoomed in on the area of Alexandria with grid 3 (200 m resolution).

than all the others (see Tonini et al. (2011) for the town of Catania; see also Table 3 in Sørensen et al. (2012), where the disaggregated weight of the single scenarios is estimated for various towns in the Mediterranean).

Of interest is also the field of the maximum value of the speed of the material fluid particles, whose aggregate is depicted in Fig. 17. Notice that in this example the portrayed field is restricted to the offshore region and does not extend into the flooded area on land. Expectedly, the velocity is low far from the coast where the water is deeper, and increases in the shallow water region near the shore. The zones of the highest speed values, exceeding $3 \mathrm{~m} \mathrm{~s}^{-1}$, include the tip of the breakwaters and the narrow mouths of the harbours, especially in the eastern and western ports of Alexandria.

\section{Exposure and vulnerability}

Exposure and vulnerability to tsunamis are concepts often used, but rarely well defined in tsunami studies, in spite of the abundant literature on tsunami hazard, vulnerability, risk and resilience that has particularly been flourishing since the megatsunamis of December 2004 in the Indian Ocean and of March 2011 in Japan. Indeed, in spite of attempts to systematize the conceptual framework, often researchers use the same terms for different concepts or different words for the same concept (see the discussion on different approaches made by Birkmann and Fernando, 2008; see also Camarasa Belmonte et al., 2011). It is not in the scope of this paper to provide a critical review of the subject, but for the sake of clarity it is relevant to highlight the main concepts we use in our application. In this paper, the vulnerability of an element (or asset) to a tsunami is related to its capacity or ability to resist the tsunami impact and depends on the properties of the element. Usually one considers two broad categories of elements (physical inanimate objects, like buildings, cars, vessels, boulders, and the animate beings, like animals and persons), that can be taken individually or in groups (e.g. com- 

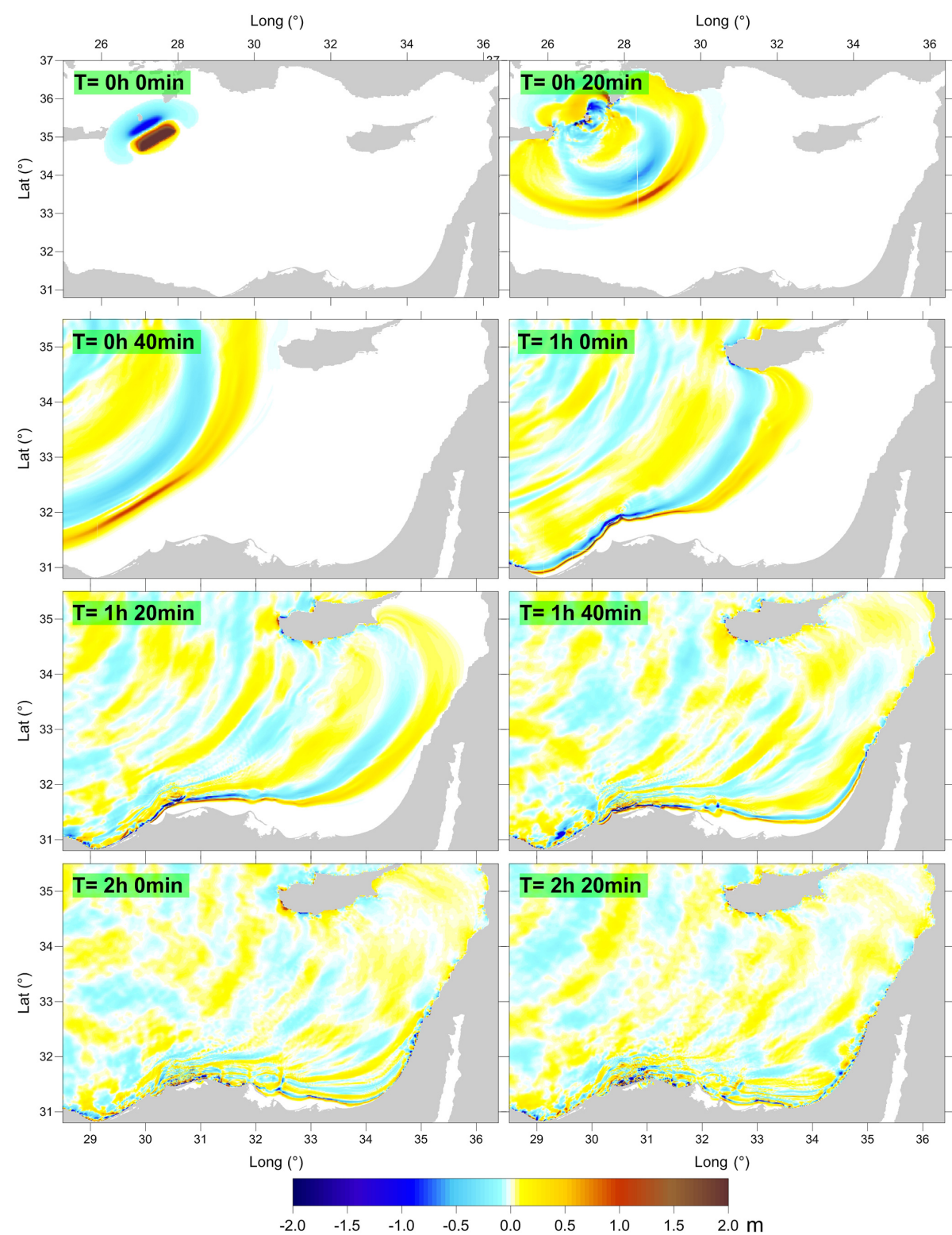

Figure 9. Propagation fields for the EHA tsunami scenario. Snapshots taken every $20 \mathrm{~min}$. Fields from $t=0$ to $t=20 \mathrm{~min}$ are plotted in grid 1; the other ones are plotted in grid 2.

plex of buildings, marinas with boats and yachts, coastal forests, cultivated lands, passengers of ferries, tourists at the beaches, ...), and that can be also assembled at a higher level of complexity (examples of vulnerable elements that can be placed at the top of the complexity hierarchy are ecosystems or social communities like villages and towns, ...). The more complex the element under study is, the more difficult it is to measure its capacity of resisting the attack of a tsunami and, consequently, the harder it is to provide properties and criteria to measure its vulnerability. And it is exactly in the attempt of coping with a wide range of complexities that often researchers mix up concepts and place undefined boundaries between hazard, exposure, vulnerability, risk and resilience.
In this paper, we will only focus our attention on the vulnerability of buildings, and we will leave the assessment of the vulnerability of more complex elements to further analyses. As for tsunami exposure, we simply consider that an element is exposed to a tsunami if it is found in an area that can be reached by the tsunami. Therefore, elements that are in the sea, like vessels and offshore structures are exposed, while elements that are on land, like edifices or persons are exposed if their positions fall within the inundation area, and not exposed if they happen to be outside the inundation area. This simple definition identifies the exposure with the geographical position of the elements, that of course can be static (for a building), or variable in time (for persons who might be 
Table 3. Building classes according to the project SCHEMA (Valencia et al., 2011). Any reference to building exposure is removed.

\begin{tabular}{|c|c|c|c|}
\hline Class & & Building attributes & Storeys \\
\hline \multirow{3}{*}{$\begin{array}{l}\text { I. Light } \\
\text { constructions }\end{array}$} & A1 & very light isolated constructions; wooden, timber, clay materials & $\begin{array}{l}0 \text { to } 1 \text { levels, } \\
\text { rarely } 2\end{array}$ \\
\hline & A2 & $\begin{array}{l}\text { very light constructions without any design (like in a } \\
\text { shanty town); a very rudimentary set of huts, built using } \\
\text { wood, clay, timber and slabs of zinc }\end{array}$ & 1 level only \\
\hline & A3 & $\begin{array}{l}\text { very concentrated light constructions (like in old } \\
\text { towns); wooden, timber and clay materials }\end{array}$ & 1 level only \\
\hline \multirow{3}{*}{$\begin{array}{l}\text { II. Masonry } \\
\text { constructions } \\
\text { and non- } \\
\text { reinforced } \\
\text { concrete }\end{array}$} & $\mathrm{B}$ & non-reinforced brick; cement, mortar walls, fieldstone, masonry & 1 or 2 levels \\
\hline & $\mathrm{C}$ & $\begin{array}{l}\text { individual buildings, villas; brick with reinforced } \\
\text { column and masonry filling }\end{array}$ & 1 or 2 levels \\
\hline & $\mathrm{D}$ & $\begin{array}{l}\text { large villas or collective buildings, residential or } \\
\text { commercial buildings; non-reinforced concrete }\end{array}$ & 1 to 3 levels \\
\hline \multirow{2}{*}{$\begin{array}{l}\text { III. } \\
\text { Reinforced } \\
\text { concrete } \\
\text { constructions }\end{array}$} & E1 & $\begin{array}{l}\text { residential or collective structures or offices, car parks, } \\
\text { schools; reinforced concrete, steel frames }\end{array}$ & 0 to 3 levels \\
\hline & E2 & $\begin{array}{l}\text { residential or collective structures or offices, car parks, } \\
\text { schools, towers; reinforced concrete, steel frames }\end{array}$ & $>3$ levels \\
\hline
\end{tabular}

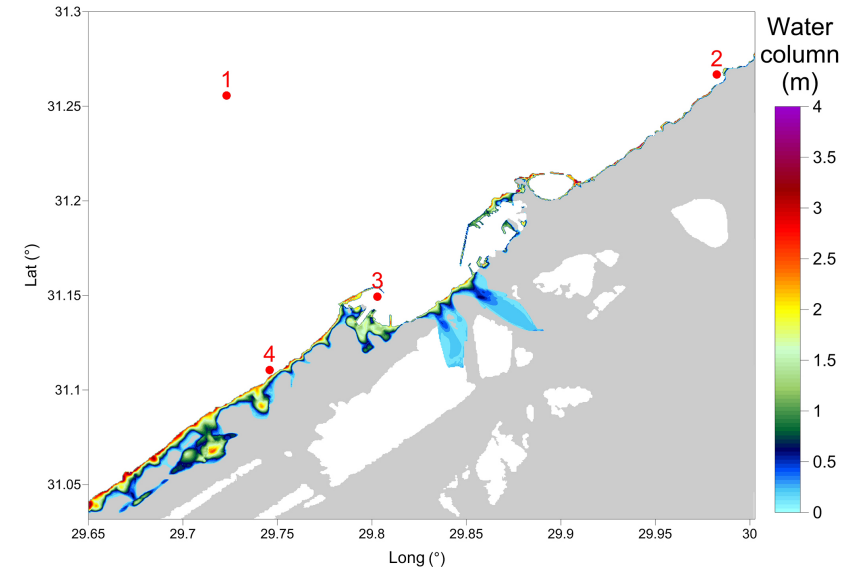

Figure 10. Water depth maxima on land for the EHA case plotted in grid 4 (40 m resolution) in mean-sea-level conditions. See caption of Fig. 6 for further details.

on a beach susceptible to flooding in the day, and in a house far away from the sea in the night). Since the extension of the flooded area depends on the analysed tsunami scenario, as was shown in the previous sections where the WHA, the EHA and the CA tsunamis were investigated, the number of elements exposed also varies from case to case accordingly.

In the framework of the above definitions, the goals of our work are to assess the vulnerability of buildings that are found inside the inundation area of the aggregate scenario (shown in Fig. 16) and to estimate the number of persons that are exposed to tsunamis.

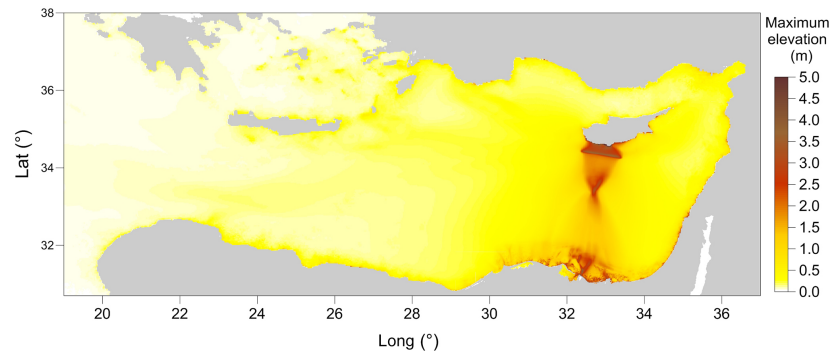

Figure 11. Sea surface maxima in grid 1 for the tsunami generated by the Cyprus Arc (CA) earthquake (see Table 1 for details).

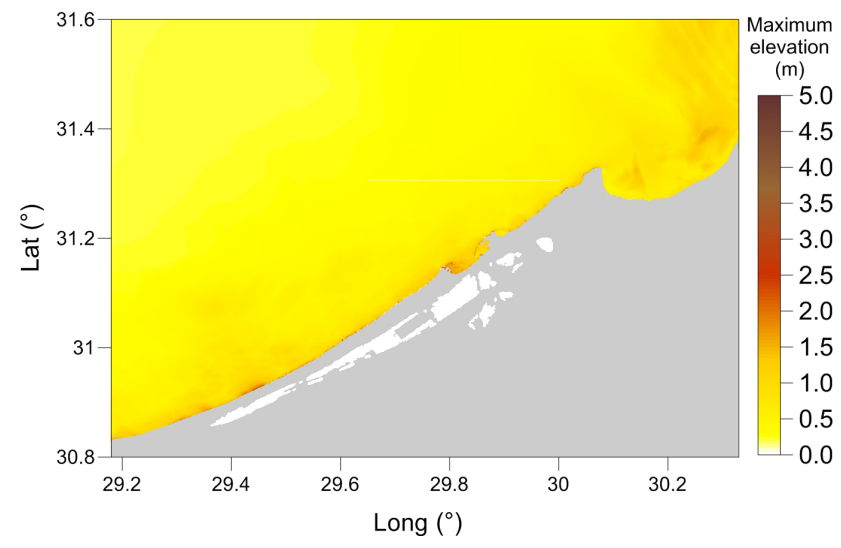

Figure 12. Sea surface maxima for the CA source, zoomed in on the area of Alexandria with grid 3 (200 m resolution). 

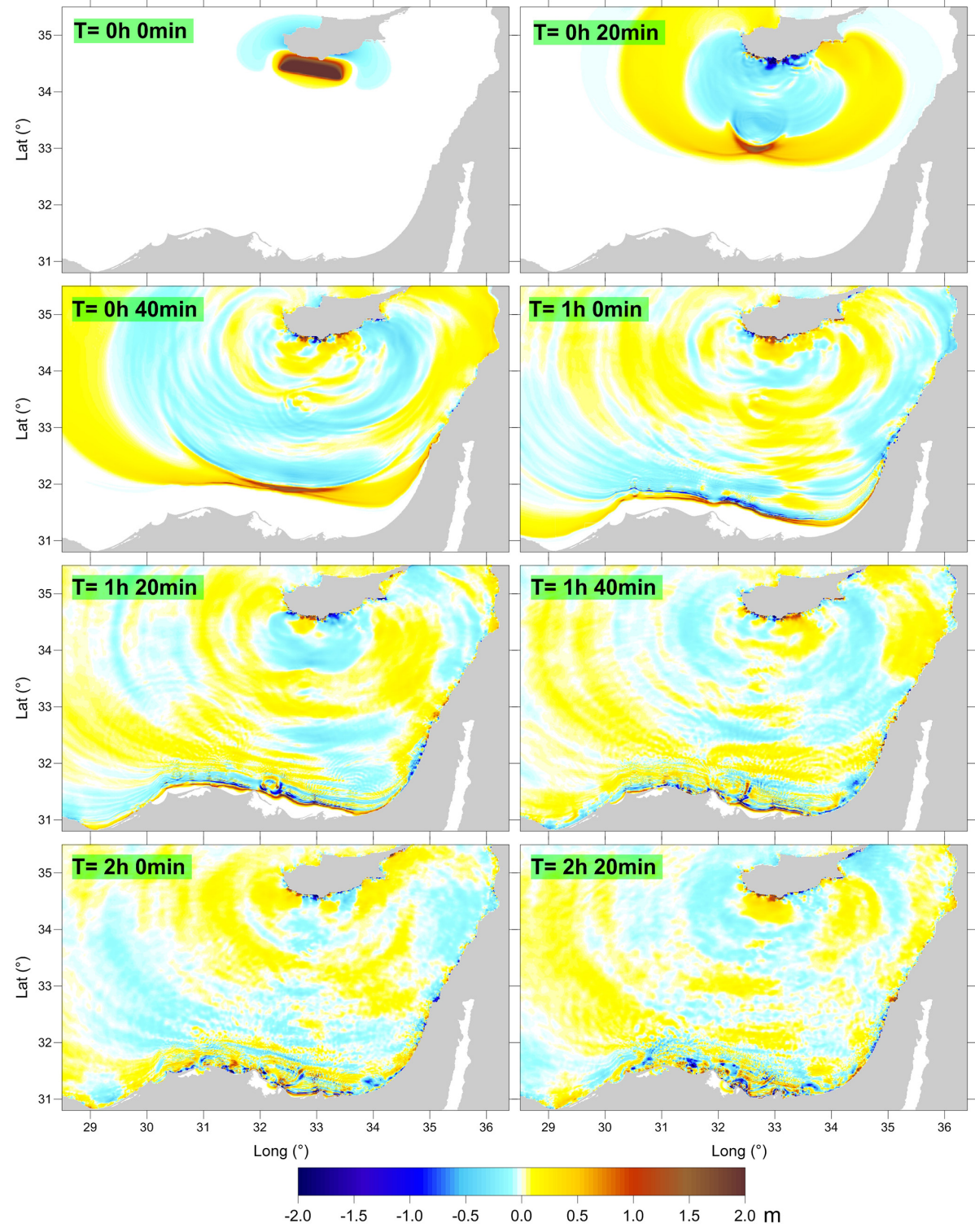

Figure 13. Propagation fields for the CA tsunami scenario. Snapshots taken every $20 \mathrm{~min}$. All fields are plotted in grid 2 .

\section{Buildings' vulnerability assessment}

Tsunami vulnerability is still a new science and has basically derived its chief analysis tools from earthquake and flood vulnerability sciences that have a much longer tradition. The main idea is that the vulnerability of an asset is described by means of damage functions. A damage function puts in relation one or more hydrological parameters of the tsunami with the damage level of the asset and can be inferred from empirical data (i.e. post-event field surveys or laboratory experiments), from numerical simulations (e.g. theoretical studies of the structural effects of tsunami waves and currents) and by means of heuristic analyses, or through a combination of these methods. Though it is known that tsunami loading on buildings is exerted via a number of various hydraulic forces (hydrostatic, surge, impact, buoyancy, etc.) that act in combination, in most studies the tsunami parameters taken into account are the height of the water column and less often the horizontal velocity of the flow and the momentum flux (that is the product of the column water height by the squared velocity). Unfortunately, the speed of the tsunami stream is quite difficult to determine for real tsunamis in the flooding areas and has only been measured in exceptional cases (see Fritz et al., 2012). Instead, the height of the tsunami and tsunami run-up are standard observables of the tsunami postevent surveys. There is no surprise, therefore, that most of the damage functions in the literature are based on the height of the water column, also known as the flow depth (see Ruan- 


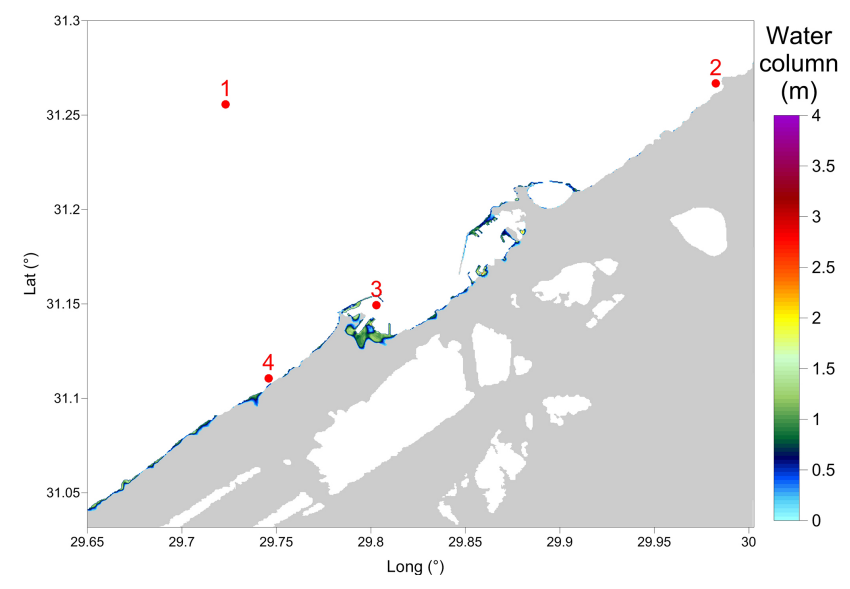

Figure 14. Water depth maxima on land for the CA case plotted in grid 4 (40 m resolution) in mean-sea-level conditions. See caption of Fig. 6 for further details.

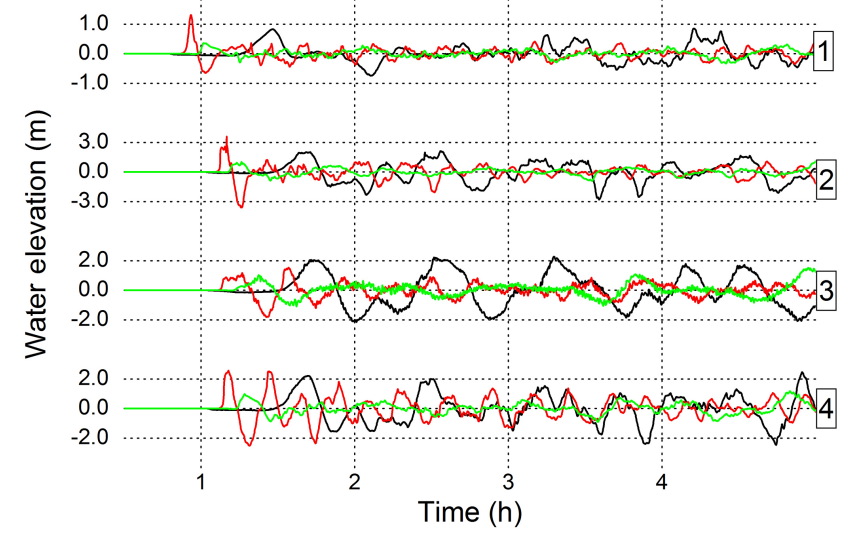

Figure 15. Time series calculated in the four positions shown in Fig. 6 for mean-sea-level conditions: the black line denotes the WHA tsunami, the red line the EHA tsunami and the green line the CA tsunami.

grassamee et al., 2006; Koshimura et al., 2009a, b; Suppasri et al., 2013).

In this paper we make use of damage functions that are specific for different categories of buildings based on the work by Leone et al. (2011) on the Indian Ocean tsunami, who identified classes and subclasses of buildings mainly on the grounds of their structural materials and characteristics. These classes were revisited and adapted to the EuroMediterranean buildings in the European project SCHEMA, where the original damage functions were also reappraised and modified (Valencia et al., 2011; Gardi et al., 2011). The five main buildings classes from $\mathrm{A}$ to $\mathrm{E}$ considered in this paper are briefly summarized in Table 3 in a version where all references to the buildings position are removed, since, according to our definition given above, the geographical position of any asset pertains to the asset exposure rather than to the asset vulnerability. For each building class, Valencia

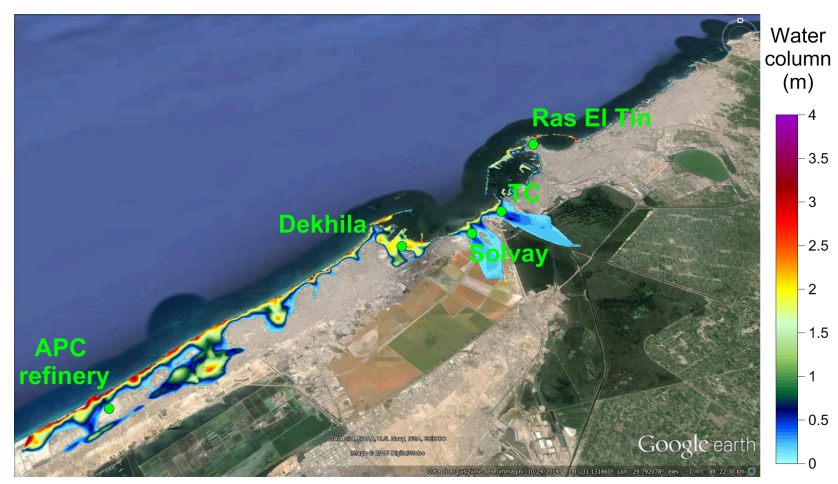

Figure 16. Aggregate field of water depth maxima on land (grid 4), obtained by combining the results of the WHA, EHA and CA scenarios and superimposed on a Google Earth image. Tsunami simulations have been computed, assuming mean-sea-level conditions.

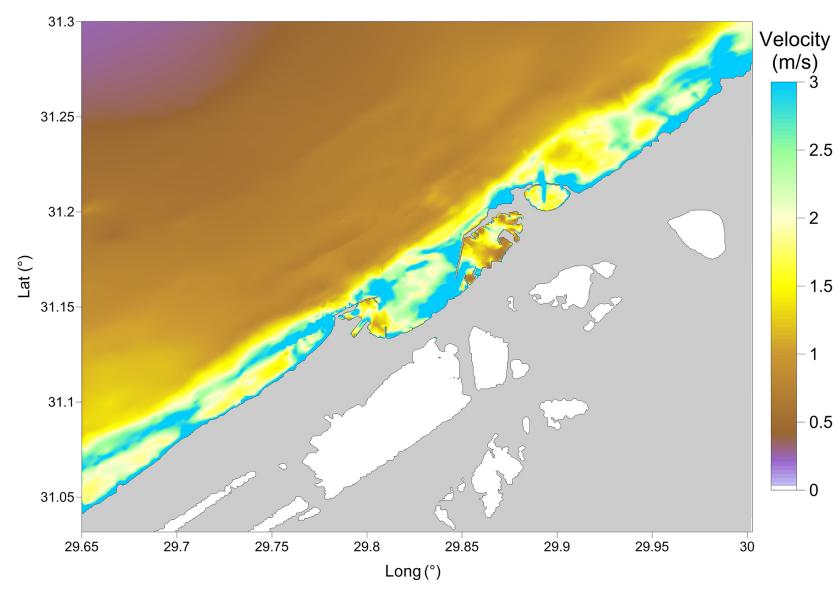

Figure 17. Aggregate field of velocity maxima calculated in the finest grid (40 $\mathrm{m}$ resolution) assuming mean-sea-level conditions.

et al. (2011) defined six levels of damage from D0 (no damage) to D5 (total collapse), and, as a first stage, determined the corresponding fragility curves, providing the probability that a building of that class might sustain damage $\mathrm{Dj}$ $(j=0,1, \ldots, 5)$ as a function of the maximum flow depth. In the second stage, from the fragility curves, they determined the damage functions, providing the maximum damage $\mathrm{Dj}$ expected for a building of a given class as a function of the maximum flow depth. A synoptic view of these curves is summarized in the damage matrix of Table 4, where each column represents the discrete version of a damage curve for a specific class of buildings. Note that the damage matrix used in this study and presented in Table 4 is a modified version of the original table by Valencia et al. (2011). In that formulation, a single damage level ("light damage") was attributed to any building affected by a flow depth in the interval $0-1.8 \mathrm{~m}$. The field observations carried out for recent events like the 2011 Tohoku tsunami evidenced that this assumption is not appropriate, as described and discussed for instance by Sup- 
Table 4. Building damage matrix after the project SCHEMA (Valencia et al., 2011) modified in building classes A and B following the fragility curves proposed by Reese et al. (2007). The first column reports the description of the damage level. The columns from A to E give the flow depth intervals in metres. Notice that damage D0 is attributed only to buildings reached by no tsunami waves.

\begin{tabular}{lllllll}
\hline \multicolumn{1}{c}{ Damage level } & & Class A & Class B & Class C & Class D & Class E \\
\hline No damage & D0 & 0 & 0 & 0 & 0 & 0 \\
Light damage & D1 & $0-0.5$ & $0-1$ & $0-2$ & $0-2.8$ & $0-3$ \\
Critical damage & D2 & $0.5-1$ & $1-2$ & $2-4$ & $2.8-4.5$ & $3-6$ \\
Heavy damage & D3 & $1-2$ & $2-4$ & $4-6$ & $4.5-6.5$ & $6-9.5$ \\
Partial collapse & D4 & $2-3$ & $4-5$ & $6-8$ & $6.5-9$ & $9.5-12.5$ \\
Total collapse & D5 & $>3$ & $>5$ & $>8$ & $>9$ & $>12.5$ \\
\hline
\end{tabular}

pasri et al. (2013). In that work, tsunami damage analyses performed on about 250000 buildings after the Tohoku event showed that for an inundation depth of 1 to $1.5 \mathrm{~m}$, more than $10 \%$ collapsed and about $55 \%$ suffered major damages. To account for this variability, we modify classes A, B and C in Table 4: in particular, with respect to Valencia et al. (2011), class A is completely redefined, class B is modified for levels D0-D4 and class C is modified for levels D0-D1. The modifications we propose derive from the fragility curves reported in Reese et al. (2007) on the basis of the damage observed after the 17 July 2006 Java tsunami.

The matrix provides a tool that is very simple and easy to implement; if one knows the maximum flow depth attacking a building of a specific class, the matrix renders the maximum expected resultant damage (see e.g. the applications by Atillah et al. (2011) and Ribeiro et al. (2011) in the framework of the project SCHEMA).

\section{Buildings damage analysis}

The aggregate inundation area is portrayed in Fig. 16 on a Google Earth image encompassing the whole coast of Alexandria from Al-Amriyah and El-Agami to Al-Montazah. It shows that for the whole coastline to the north-east of the old town, extending from Al-Gomrok to Al-Montazah (see toponyms in Fig. 1), where most of modern residential Alexandria has been built, the inundation is limited only to beaches, since the coastal ridge is high enough not to be overtopped by tsunami waves. On the contrary, the inundation in the zone from the eastern port to Al-Amriyah and El-Agami is more severe and in some areas penetrates deep in the interior. All the three harbours here (the eastern and western ports and the Dekhila port) are inundated, which may be better recognized in the zoom of Fig. 18. In the eastern and western ports, inundation affects the breakwaters and the former island of Pharos, that is the docking area for cruise ships, as well as the area of Ras el-Tin Palace and the Ras el-Tin beach. In the Dekhila port, where the main activity is loading/unloading of cargos, the sea water goes about $2-3 \mathrm{~km}$ far from the sea line, flooding the container terminal and deposits, silos, tanks, etc. The area suffering major inundation

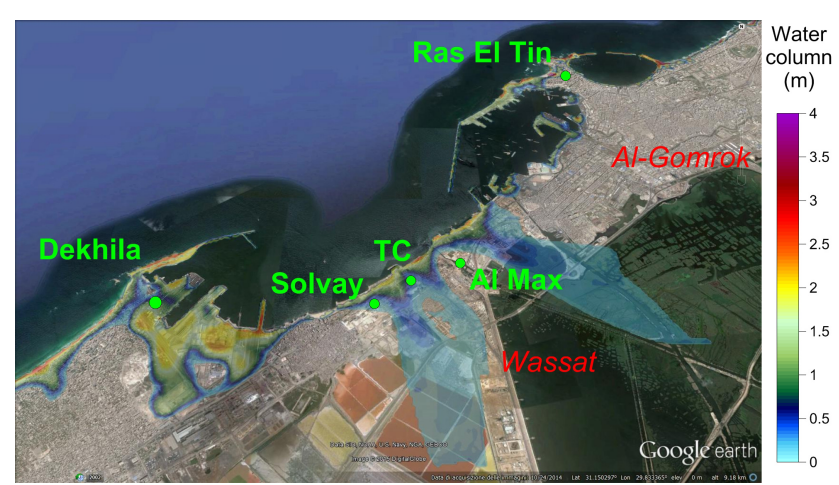

Figure 18. Zoom of the inundation area between the port of Dekhila and the port of Alexandria (covered by grid 4) under the assumption of tsunamis attacking in mean-sea-level conditions. A couple of toponyms and places of relevant industrial installations are also shown: Solvay represents Alexandria Sodium Carbonate, TC represents Titan Cement.

is found in Wassat, around $\mathrm{Al} \mathrm{Max}$, where there is no protection from the outer breakwater and where two flooding tongues penetrate $4 \mathrm{~km}$ deep (see Fig. 18) following topographical lows corresponding to the drainage channels of the Lake Maryut. Here the flooded area is occupied by big industrial plants and installations (e.g. the Solvay Alexandria Sodium Carbonate company, which is the main producer of soda ash for the domestic Egyptian market; the Titan Cement company, a multinational company based in Greece that acquired the most important Egyptian cement producer in 2008; and the Alexandria Petroleum Company refinery); whereas the $\mathrm{Al}$ Max residential quarters are located at a level high enough to be almost untouched.

To the south-west of Dekhila, the inundation is very strong and involves further installations of the Alexandria Petroleum Company refinery to the west, and a vast residential area in Abu Talat and in El-Agami (Fig. 16). Since in this paper our main interest is in the assessment of damage to buildings, we concentrate our analysis on this area. Indeed, the damage matrix of Table 4 is inadequate for industrial installations and infrastructures, which should rather be analysed by means of specific studies, since in this case not only 


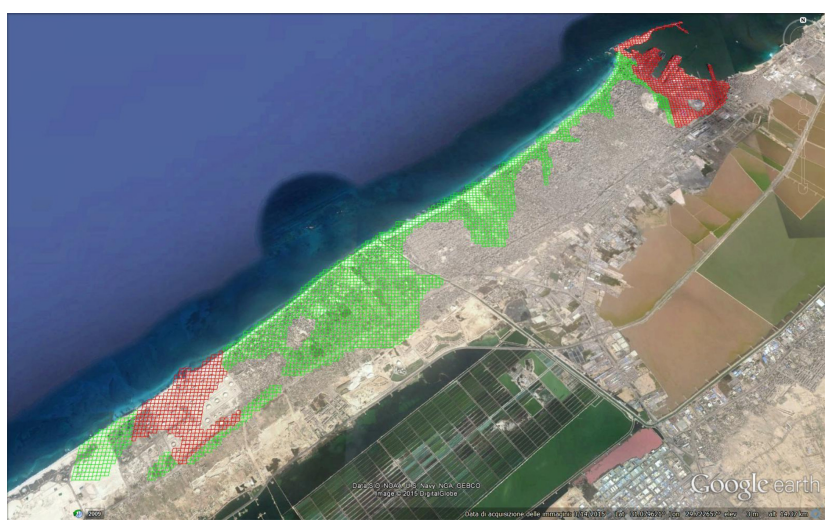

Figure 19. Map with meshes ( $80 \mathrm{~m}$ resolution) used for buildings' vulnerability assessment focussed on the zone south-west of the Dekhila port. The green mesh covers the area of inundation, while the red one is a subset covering the area of Dekhila port (north) and the area of APC refinery (south) not considered for the vulnerability analysis. Assumption is made of mean-sea-level conditions.

the direct effects are of importance, but the induced cascade effects might be even more relevant and worth a thorough investigation (see the disaster following the meltdown of three reactors of the Fukushima Daiichi nuclear power plant induced by the Japan 2011 tsunami; see also Cruz et al., 2011). Therefore, we will leave this subject for further studies.

The buildings' damage analysis in the area to the southwest of the Dekhila port is essentially based on images of the Google Earth database, including satellite imagery and ground pictures. Since the beginning of vulnerability assessment science, remote sensing with global coverage has been seen as a powerful and practical tool to conduct vulnerability studies over vast coastal areas. It is worth stressing that from the experience gained in very many applications it has been shown that though ground surveying is necessary to validate remote-sensing-based analyses, often it results only in slight corrections, and a few control points may suffice for a good validation (see Tonini et al. (2011), and Pagnoni et al. (2014) for buildings' vulnerability studies on eastern Sicily towns).

In this paper, the buildings' damage analysis was performed according to the following five-step procedure.

Step 1 consists of the area of inundation resulting from the envelope scenario with $40 \mathrm{~m}$ resolution being put in a Google Earth file format. This allows one to import the inundation area in the Google Earth satellite images, as displayed in Figs. 16 and 18 already referred to above. Here it is worth stressing that the need to superimpose the computed inundation area to georeferenced Google Earth images derives from the fact that the potential tsunami damage is estimated by cross-checking data of tsunami inundation (available in maps produced by the tsunami simulation code UBO-TSUFD) with data on the buildings, inferable from the Google Earth satellite most recent images (acquired on 20 January 2015 and on 18 April 2015). It is worth further

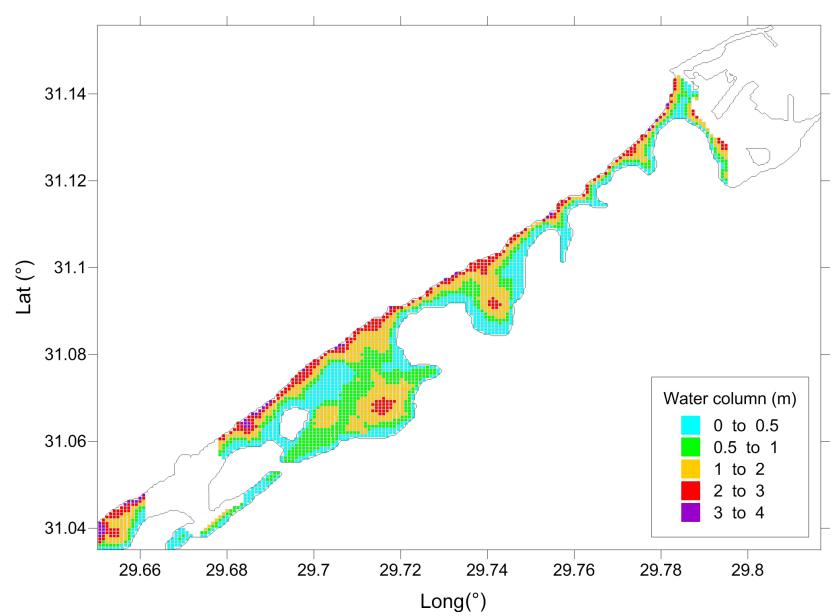

Figure 20. Tsunami flow depth under the mean-sea-level hypothesis in the zone to the south-west of the Dekhila port, discretized on the $80 \mathrm{~m} \times 80 \mathrm{~m}$ cell tessellation that has also been used to assess the damage to the buildings.

underlining that such images are quite recent in the whole Alexandria region, since they were mostly acquired in the years 2014 and 2015.

Step 2 consists of the land use characterization of the flooded area with the purpose of identifying the zones with buildings on which the vulnerability and damage analysis will be focussed. This enabled us to concentrate the analysis on the zone to the south-west of the Dekhila port illustrated in green in Fig. 19 and to discard other sectors of the aggregate flooded area because either they are industrial zones (APC refinery) or container terminals (Dekhila port) (see the red zones of Fig. 19) or they have basically no buildings (e.g. beaches, swamps ....).

Step 3 is the creation of a discretization grid suitable for both flow depth analysis and buildings' vulnerability analysis. When no automatic digital tool for image processing is available and when the extension of the inundation area is large, painstaking visual inspection can be a very difficult and time-consuming process, with costs increasing with the grid resolution. In our study we have considered, as a useful compromise, an $80 \mathrm{~m}$ resolution tessellation, by which we have covered the part of the inundation area resulting from the selection of step 2. Figure 20 portrays the flow depth (water column height) of the envelope scenario for the $80 \mathrm{~m}$ grid, that is easily built from the $40 \mathrm{~m}$ grid of the tsunami numerical model by proper node selection, since the size of the tessellation grid cell is a multiple of the simulation grid. This is an advantage but is not a strict requirement, since all normal interpolation methods are straightforward and adequate to compute coarser fields from higher resolution maps. From the flow depth map (Fig. 20) one can observe that the highest values are in the range of 3-4 m and that they are mostly found close to the shoreline. Expectedly the flow depth decreases moving landward, but there are two remarkably high 

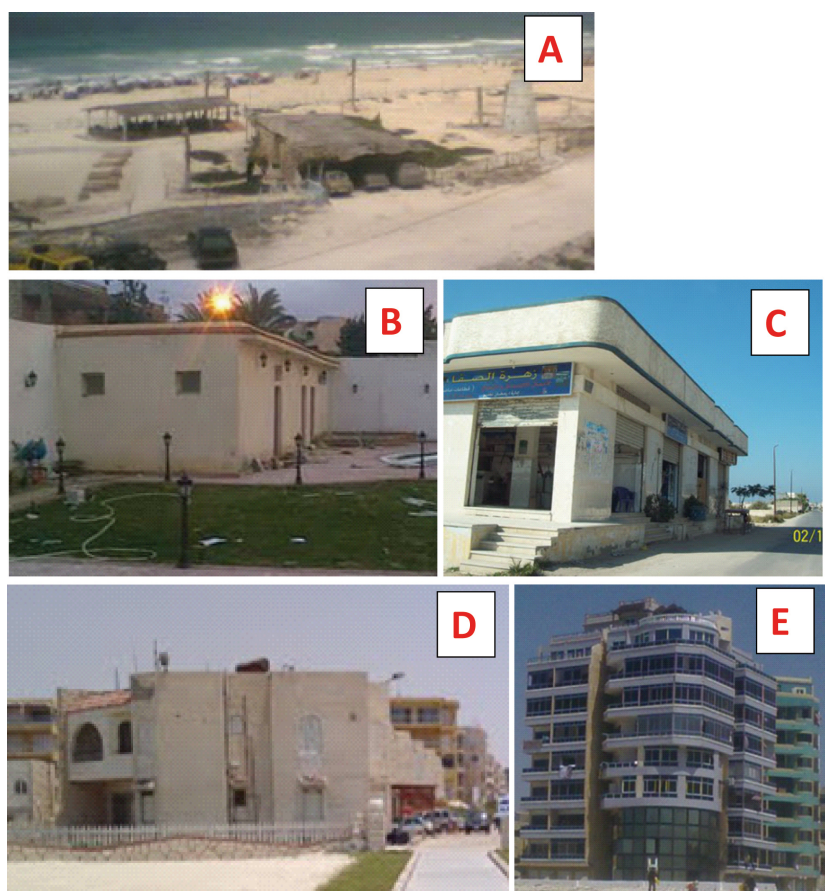

Figure 21. Typical constructions of classes from A to E in Alexandria (pictures from Google Earth database).

zones with values between 2 and $3 \mathrm{~m}$ (red in the figure) that can be explained as the effect of local topographic lows.

In step 4, by making use of the adopted tessellation, we identify all the buildings that are located within the selected portion of the inundation area and assign each of them to one of the five buildings classes from A to E given in Table 3. Figure 21 provides Google Earth pictures of buildings typical of each class. The analysis is performed for each cell of the tessellation. We have counted a total of 2433 inundated cells, covering an area of about $15.571 \mathrm{~km}^{2}$. At this stage, a more accurate inspection showed that as many as 479 cells (around $20 \%$ of the total) have no buildings: most of these are located on the coast and cover the area between the coastline and the first line of buildings (see Fig. 22 displaying the map of the building density per cell). It is worth observing that in attributing the building to a given cell, buildings on the cell boundary are counted in the cell if their footprint is inside the cell in a proportion larger than $50 \%$, which entails some degree of overestimation; with a bias that is larger in percentage, the smaller the cell size is. However, when deducing the flow depth in each cell (which is done in step 3), the bias decreases along with the cell size. This explains that a further requirement of the step 3 tessellation (in our case $80 \mathrm{~m}$ ) has to be a compromise between the counting of buildings (the estimate improves with the size of the cells) and the assumption that the value of the inundation depth is constant within a cell (the approximation worsens with the cell size). The total number of constructions within the flooded zone has been found to exceed 12000 . Most of them are brick houses with
Table 5. Vulnerability classification of the buildings inside the aggregate inundation area selected in step 2 of the procedure. It extends over $15 \mathrm{~km}^{2}$. Data refer to the mean-sea-level case.

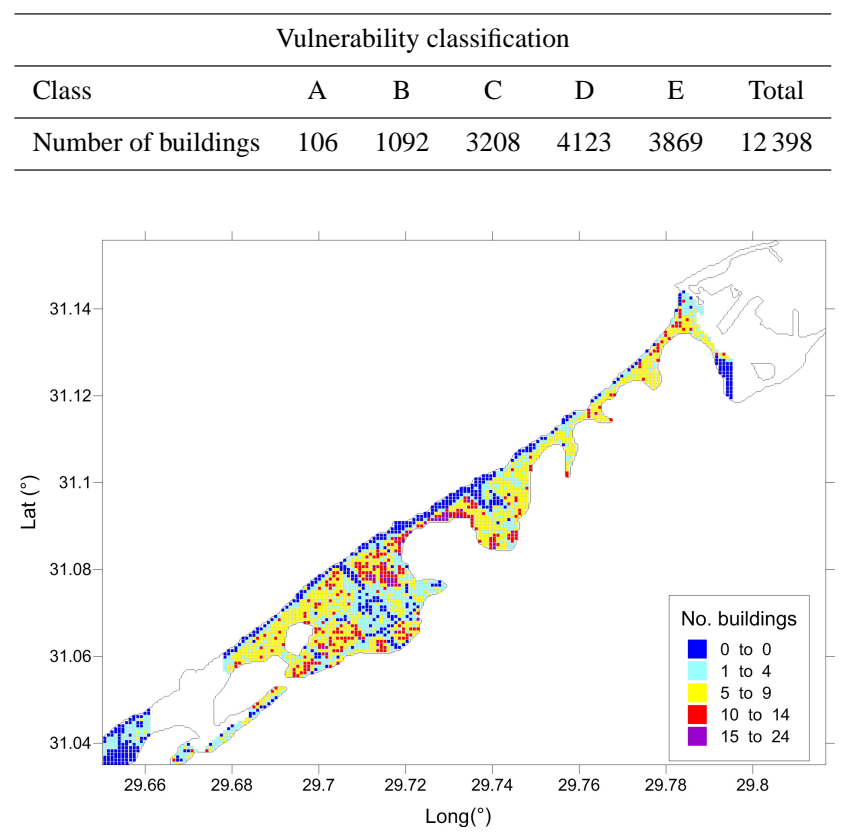

Figure 22. Map of the building density per cell for the $80 \times 80 \mathrm{~m}$ tessellation. Most of the "no buildings" cells are found along the shore or along stream banks. Most of cells are in the group of five to nine buildings per cell (yellow).

some reinforced structural elements (class D), or mere brick houses (class $\mathrm{C}$ ) or more solid buildings with reinforced concrete (class E) and only a few are weak brick houses (class B) or light constructions (class A). The distribution of buildings into the adopted SCHEMA classes is shown in Table 5. The number of buildings per cell, that can also be seen as a building density, is shown through the histogram of Fig. 23 and the map of Fig. 22. To help readability, all classes of Fig. 23 have a width of 2 and are denoted on the horizontal axis with an even number. This means that a generic class denoted by $2 n$ contains all tessellation cells counting either $2 n-1$ or $2 n$ buildings. The first class is an exception: it has a width of 1 since it only contains cells with 0 buildings. Of the 2433 $(80 \mathrm{~m} \times 80 \mathrm{~m})$ cells, as many as 479 result in having no constructions, as already noted before. Considering only the occupied cells, one observes that the highest columns of the histograms are the classes ranging from three to eight buildings. Further, the average density results in having $5.1 \mathrm{bpc}$ (here bpc stands for buildings per cell) and, if one restricts the analysis only to the occupied cells, it increases to about $6.3 \mathrm{bpc}$. The building density map (Fig. 22) shows that "no buildings" cells are found (i) along the shoreline, (ii) in alignments normal to the shore, corresponding to stream banks and (iii) in areas close to the industrial (on the left) and port (on the right) installations. 
Table 6. Damage to buildings and exposed persons under the hypothesis of mean-sea-level conditions.

\begin{tabular}{|c|c|c|c|c|c|c|c|c|c|c|}
\hline \multirow{2}{*}{$\begin{array}{l}\text { Flow } \\
\text { depth } \\
\text { (m) }\end{array}$} & \multirow{2}{*}{$\begin{array}{l}\text { Number } \\
\text { of cells }\end{array}$} & \multirow{2}{*}{$\begin{array}{l}\text { Area } \\
\left(\mathrm{km}^{2}\right)\end{array}$} & \multirow{2}{*}{$\begin{array}{r}\text { Number } \\
\text { of } \\
\text { buildings }\end{array}$} & \multicolumn{6}{|c|}{ Number of buildings } & \multirow[t]{2}{*}{ Persons } \\
\hline & & & & D0 & D1 & D2 & D3 & D4 & D5 & \\
\hline $0.0-0.5$ & 744 & 4.76 & 4809 & 0 & 4809 & 0 & 0 & 0 & 0 & 59702 \\
\hline $0.5-1.0$ & 685 & 4.38 & 3881 & 0 & 3866 & 15 & 0 & 0 & 0 & 48181 \\
\hline $1.0-1.5$ & 395 & 2.53 & 2018 & 0 & 1808 & 189 & 21 & 0 & 0 & 25052 \\
\hline $1.5-2.0$ & 280 & 1.79 & 1118 & 0 & 972 & 123 & 23 & 0 & 0 & 13879 \\
\hline $2.0-2.5$ & 185 & 1.18 & 396 & 0 & 209 & 85 & 74 & 28 & 0 & 4916 \\
\hline $2.5-3.0$ & 107 & 0.68 & 141 & 0 & 68 & 40 & 22 & 11 & 0 & 1750 \\
\hline $3.0-4.0$ & 37 & 0.24 & 35 & 0 & 0 & 27 & 3 & 0 & 5 & 434 \\
\hline Total & 2433 & 15.57 & 12398 & 0 & 11732 & 479 & 143 & 39 & 5 & 153916 \\
\hline
\end{tabular}

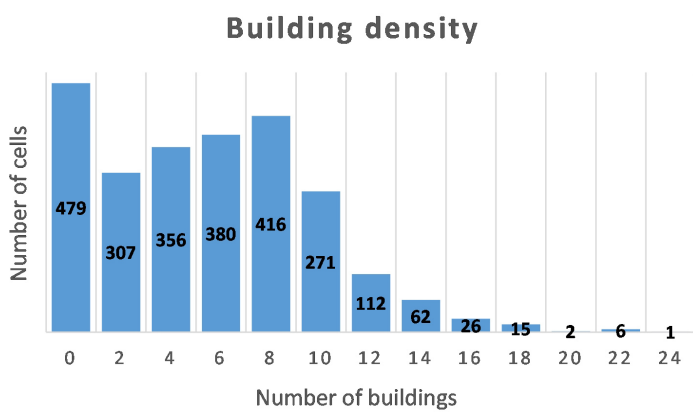

Figure 23. Distribution of buildings per cell in the inundated area selected in step 2 (see text). Each class is denoted by an even number. All classes, but the first on the left, have a width of 2 . This means that the column denoted by 2 contains all cells having either one or two buildings, the next denoted by 4 contains cells with three or four constructions, etc. Instead, the first column contains only cells with no buildings. Figures in the columns are the number of cells.

Step 5 of our procedure is the evaluation of the damage that each building might sustain by applying the modified damage matrix shown in Table 4 . The result of the analysis is summarized in Table 6 . The first four columns give, respectively, the flow depth discretized in steps consistent with the damage matrix, the corresponding number of cells, the area they cover and the overall number of buildings they contain. From the table, one sees that the number of cells, and therefore the corresponding area, decreases strongly as the flow depth increases. The area where the sea level is found to be less than $1 \mathrm{~m}$ is as much as $59 \%$ of the total, while only $5.8 \%$ is inundated by more than $2.5 \mathrm{~m}$ of sea water. Consequently, the number of affected buildings (column 4 of the table) is also an inverse function of the flow depth. It is worth noting that the building density in the least inundated cells turns out to be $5.56 \mathrm{bpc}$ which is somewhat larger than the average $(5.1 \mathrm{bpc})$. Notice further that this density tends to decrease as the flow depth increases; it is $4.0 \mathrm{bpc}$ for the central flow depth class $(1.5-2 \mathrm{~m})$ well below the average, and decreases to the extreme value of $0.95 \mathrm{bpc}$ for the most inundated cells. This shows that the areas subject to the highest tsunami inundation (usually found close to the shoreline or the river banks) have been traditionally considered by local people not adequate for population settlements. Determining if this has occurred as the result of specific tsunami hazard awareness or of more generic flooding hazard awareness or of other reasons related to the construction technique (inadequacy of soil for foundations) is outside of the scope of the present analysis. However it is a noteworthy feature since it has a positive consequence on reducing the potential tsunami damage.

The other columns of Table 6 display the frequency distribution of the damage level from D0 to D5. Notice that since by choice all the considered buildings are found inside the inundation area, none of them falls in the D0 damage category, which only applies to buildings not affected by any tsunami waves. The sub-table, which includes the columns from D1 to D5, can be discussed by considering rows, i.e. the flow depth, or by considering columns, i.e. the damage level. In the first case, one may notice that when the flow depth is small (less than $1.0 \mathrm{~m}$ ), all buildings only sustain damage D1, with the exception of fewer than $0.2 \%$ of constructions sustaining damage of type D2. With higher values of flow depth, the distribution of buildings tends to be less peaked, involving also other levels of damage, and at the highest flow depth values, i.e. between 3.5 and $4 \mathrm{~m}$, some buildings are found to sustain the maximum level of damage, D5. The final result of this analysis is that 11732 buildings are expected to sustain damage not exceeding D1 (light), as many as 479 not exceeding D2 (important), 143 heavy damage (D3) and only 39 and 5 buildings can be affected by partial collapse (D4) and total collapse (D5), respectively.

The buildings' damage estimates summarized in Table 6 are the result of the 5-step procedure illustrated above where at some point we have introduced a convenient $80 \mathrm{~m}$ resolution tessellation in place of the $40 \mathrm{~m}$ grid resulting from the tsunami simulations. In doing so we have assumed that the flow depth of the envelope scenario is constant in each cell of the tessellation and have taken this constant value, say $d$, 
Table 7. Maximum and minimum number of buildings attributed to each level of damage. Notice that the number of buildings shown in the last row of Table 6 lies in between the ones of this table. Data have been computed for simulations carried out for the case of mean-sea-level conditions.

\begin{tabular}{lcrrrrr}
\hline & \multicolumn{6}{c}{ Number of buildings } \\
\cline { 2 - 7 } & D0 & D1 & D2 & D3 & D4 & D5 \\
\hline$d_{\max }$ & 0 & 11390 & 720 & 210 & 54 & 24 \\
$d_{\min }$ & 0 & 11950 & 351 & 87 & 10 & 0 \\
\hline Difference & 0 & -560 & +369 & +123 & +44 & +24 \\
\hline
\end{tabular}

to assess the damage to all constructions inside the cell, accounting for their respective vulnerability class. It is easy to see that the tessellation cell spans an area covered by four tsunami grid cells, in general with different flow depth values. If we denote the highest and smallest of such values with $d_{\max }$ and $d_{\min }$ respectively, and repeat the damage assessment using these values, we will obtain respectively higher and lower damage levels for the buildings in the cell. Table 7 gives the total number of buildings in each damage class resulting from applying the analysis in all cells of the inundation area. Comparing Table 7 with the last row of Table 6, one sees that figures computed with the flow $d$ are bracketed by the ones obtained using $d_{\max }$ and $d_{\min }$, which provides an estimate of the uncertainties deriving from the coarser discretization of the tessellation grid. In our case, the general outcomes of the damage analyses of Tables 6 and 7 do not differ substantially, and therefore the $80 \mathrm{~m}$ resolution can be considered acceptable in this respect.

The vulnerability analysis illustrated here is the result of the careful identification of the building types that are located in each single cell of the tessellation, which is a manual procedure taking a long time if one extends the analysis to the full set of the tessellation cells, as was done before. One could wonder how the final results are affected if one takes only a suitable selected cells sample into consideration. For this purpose, we have selected a number of random samples, each of 243 cells, thus corresponding to $10 \%$ of the total tessellation set. The results are shown and discussed in the Appendix A1.

\section{Population exposure analysis}

The population exposure is computed from census data of Alexandria. Since we are considering a residential area, we assume that there is no seasonal variability, which is usually related to touristic fluxes. Further, we neglect also the daily variability, assuming that all residents are at home, which is consistent with the worst-case scenario approach adopted in this study.

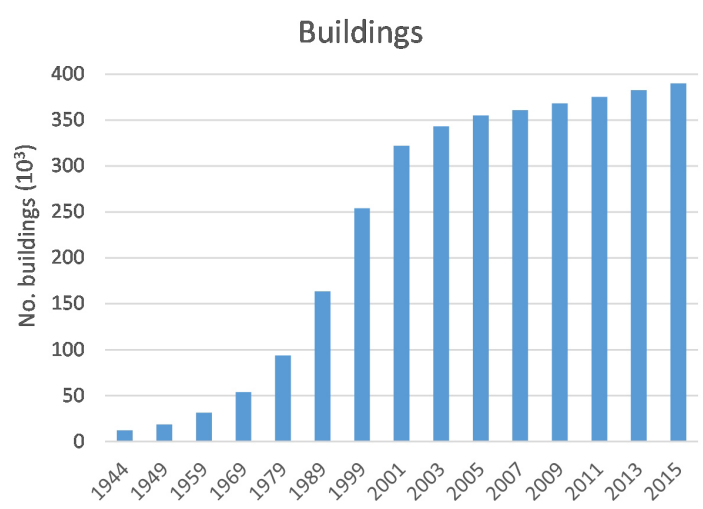

Year

Figure 24. Number of buildings in the governorate of Alexandria from 1944 until 2015.

A census in Egypt has been conducted regularly every 10 years since 1976 and there are data for the years 1937, 1947 and 1960. The last survey was carried out in 2006 by the Central Agency for Public Mobilization and Statistics (CAPMAS). The census data provided by CAPMAS regard mainly constructions and population. As to the former, one can trace the huge expansion of the building history for the whole of Egypt as well as for the individual governorates. The increase of the number of buildings for the governorate of Alexandria is shown in the histogram plotted in Fig. 24 for the interval 1944-2015 where the data of the national surveys are interpolated and extrapolated for those years not covered by the surveys. One can observe an increase of more than 10 times in the last 55 years with buildings passing from 31300 to about 390000 in 2015.

The population of Egypt has a general growing trend with an increase of more than $22 \%$ in the period from 1996 and 2006, which is rather homogeneous throughout the country. In the same decade, the population of the governorate of Alexandria grew by $20 \%$, passing from 4 million to 4.8 million people, while in the last 55 years, the population has grown by a factor slightly less than 3.3 (see the histogram of Fig. 25). By combining census data on buildings and population, one can draw the curve of the density of people per buildings as a function of time, which is also provided in Fig. 25. One can see that this density decreased remarkably and steadily down from 69.5 to about $11.6 \mathrm{ppb}$ (persons per building) in the second half of the 20th century, and that it started to increase slowly after the 2000, reaching a value of $12.4 \mathrm{ppb}$ in 2015 . This people density is the basic figure that allows us to estimate the persons resident within the aggregate inundation area shown in Fig. 20. The last column of Table 6 gives the number of exposed persons that are resident in areas with different estimated levels of flow depth, the figures of which are obtained simply by multiplying the corresponding number of buildings listed in column 4 by the average density factor of 12.4 . The total number of exposed 


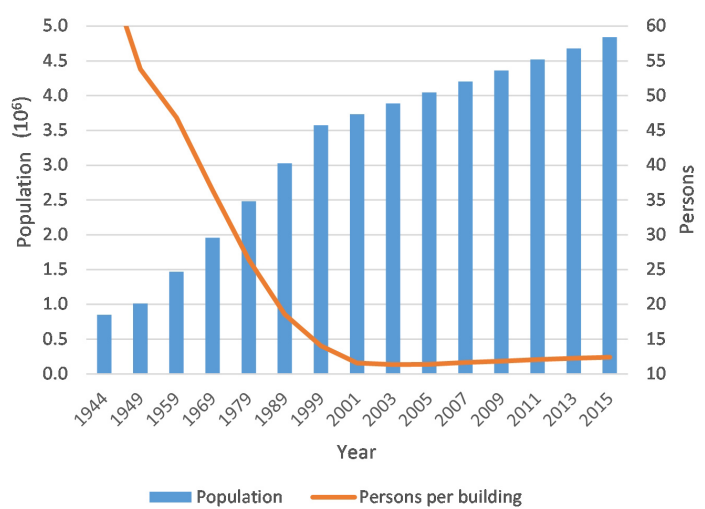

Figure 25. Population of the governorate of Alexandria (histogram) and density of persons per buildings (continuous line) from 1944 until 2015.

people is 153916 , which is quite large as an absolute value, though it is only $3.2 \%$ of the total population of the governorate. We stress that the population density we have used is the average value for the governorate of Alexandria evaluated for the year 2015 and that using values specific for the districts where the inundation area extends could provide more accurate, but expectedly not so different, estimates.

\section{Comparison with other studies}

The tsunami vulnerability of Alexandria has been the subject of only one previous paper, to the knowledge of the authors. On making use of remote sensing and field data, Eckert at al. (2012) estimated the building vulnerability of Alexandria by applying a vulnerability model that is based on flow depth values, but also on several other attributes of the buildings. Since three basic factors of the study by Eckert et al. (i.e. usage of remote sensing data, usage of field data, damage functions taking flow depth values into account) are the same as the present paper analysis, one could expect similarities in the result, which is unfortunately not true. The two studies happen to be incomparable and totally inconsistent in their conclusions, since the hazard analysis, which is a prerequisite for the vulnerability analysis, is quite different. Adopting a bathtub-like approach and skipping numerical modelling, Eckert et al. (2012) investigated two tsunami scenarios where the sea level rises by 5 and $9 \mathrm{~m}$ uniformly all along the coast of Alexandria due to a tsunami attack. Since under this hypothesis the inundation area covers the entire coast of the governorate of Alexandria, for practical reasons they restricted the analysis to the districts of Al-Gomrok and Al-Montazah (see Fig. 1 for toponyms). However, according to our study based on worst-case credible scenarios, the buildings in these two districts are almost untouched by the tsunami, since the inundated area turns out to be more to the south-west, and even here run-up values do not reach a height of $9 \mathrm{~m}$.

\section{Conclusions}

In this paper we have investigated the tsunami hazard of Alexandria by using the worst-case credible tsunami scenario analysis (WCTSA) technique. We have considered three scenarios (WHA, EHA and CA) where tsunamis are generated by big earthquakes in the subduction arcs that mark the boundary between the Africa and the Eurasia plates. All of these are remote sources, which means that seismic shaking is expected to be moderate in Alexandria and that tsunamis are the major threat. We have considered two possible levels of the sea, the mean sea level and the maximum high-tide level, that are assumed to differ by $30 \mathrm{~cm}$ in Alexandria, in agreement with tide-gauge time-series analysis.

The inundation resulting from enveloping the inundation maps of the individual cases happens to be very similar to (although not coincident) the EHA scenario, so it is therefore the predominant one; the WHA scenario adds a relevant contribution especially in the El Dekhila area. Flooding affects mostly the Alexandria coast to the west of the old town where a number of tongues (two in the area between Al-Gomrok and El Dekhila and two more to the south-west of El Dekhila) penetrate some kilometres inland beyond the coastal ridge, primarily utilizing the drainage channels of the Lake Maryut. We have applied a buildings' vulnerability model elaborated in the European project SCHEMA to estimate the damage to buildings in the affected residential areas of El Dekhila and Al-Amriyah. In case of tsunami simulations in mean-sealevel conditions, our finding is that 12398 constructions can be damaged (most of which only slightly) by the tsunami and that about 154000 residents are exposed, which corresponds to $3.2 \%$ of the total population of the governorate of Alexandria. These figures increase to 13340 for buildings and to 165308 for persons, when tsunami simulations are carried out for the maximum high-tide level conditions.

The present study can be considered preliminary and will be refined in future work. One key point is the hazard analysis that should investigate not only earthquake sources but all the possible credible large tsunami sources. In our discussion on the tsunami hazard for Alexandria we have mentioned a Holocene huge mass flow whose tsunamigenic potential was investigated by Garziglia et al. (2007). We believe that it would be interesting to investigate whether small-scale submarine sediment movements are able to generate tsunamis affecting Alexandria more severely than the earthquakeinduced tsunamis, and hence to contribute to the aggregate scenario. Further, uniform-slip earthquake sources have been assumed here, while it is well known that for all large earthquakes, the on-fault co-seismic slip occurs in patches where the slip magnitude is much higher than the average value. Third, as regards vulnerability analysis, we remark that the damage to buildings might only be a fraction of the total economic loss, especially when the area hit is full of large industrial plants with high pollution potential like the ones in the districts of Alexandria that have been analysed. In addition, 
these industries act as attraction points for workers, which increases the number of persons exposed to tsunami especially during daylight. This is also true for the port structures that are key port terminals for the whole country of Egypt. Deepening these topics is at the forefront of present-day tsunami vulnerability analysis and will be the subject of future research. 


\section{Appendix A: Further analysis}

\section{A1 Sampling of the tessellation cells}

Counting the buildings in all the cells of the area resulting from the envelope of tsunami inundation maps can be a very long procedure, taking time and resources, and increasing with the extension of the area, which can cover tens or hundreds of $\mathrm{km}^{2}$. In the case of Alexandria studied here, the inundation area covers more than $15 \mathrm{~km}^{2}$ and involves 2433 , $80 \mathrm{~m} \times 80 \mathrm{~m}$, cells and 12398 constructions. In order to reduce the time for the analysis, one might consider applying the vulnerability analysis to a subset of such cells, under the assumption that results are representative of the entire set. We have investigated this possibility by taking as many as 10 samples of the 2433 cells, each consisting of 243 cells (about $10 \%$ of the total). Each sample resulted from a random selection (corresponding from sampling a uniform distribution of integers running from 1 to 2433), tempered however by the criterion that the selected cells should be distributed almost uniformly over the entire inundation area. This latter requirement was checked by visual inspection and was used to avoid concentration of cells in specific geographic zones with properties far from the ensemble properties (e.g. with very low or very high buildings density, or with very low or very high flow depth, etc.).

To each of the 10 samples we have applied the procedure described in the paper section on vulnerability analysis, and then estimated the values for the entire set. In particular, we have counted the number of buildings for each building type from $\mathrm{A}$ to $\mathrm{E}$ and the total number of buildings of the sample. It is easy to see that if $N_{\mathrm{S}}$ is one of these numbers, the statistical standard deviation associated with it is $\sigma_{\mathrm{S}}=\sqrt{N_{\mathrm{S}}}$, and the estimates of the corresponding number for the entire set are $\alpha N_{\mathrm{S}}$ and $\alpha \sigma_{\mathrm{S}}$, where $\alpha$ is the ratio between the total number of cells and the number of cells in the sample. In our case $\alpha=10$. The results are shown in Fig. A1 where for each building type, the estimates are provided together with the error bars. They are compared with the corresponding values we obtained by using the full set of data shown in Table 6. It can be observed that for most samples, the real values (solid black lines) are within the $1 \sigma$ error bar (exception are samples 2, 5 and 6) and that for all samples, they fall within the $1.5 \sigma$ error bar.

If we extend the analysis from the above building classification to the damage evaluation, we obtain a similar plot (see Fig. A2). The number of buildings with a given level of damage obtained by the samples usually falls within the $1 \sigma$ error bar, and always within the $1.5 \sigma$ error bar. This proves that making estimates on samples can be a viable tool to obtain satisfactory results and to save analysis time, though, however, the price to pay is the introduction of some statistical error.

\section{A2 Maximum high-tide level conditions}

In Alexandria, like in most of the Mediterranean region, sea level oscillations due to tides are much less relevant than in the oceans. A 10-year long record (1996-2005) of daily sea level oscillations taken in the western port of Alexandria shows that tidal range is confined to about $60 \mathrm{~cm}$ (see ElGeziry and Radwan, 2012), of which about $18 \mathrm{~cm}$ are due to the astronomical tide contribution and the rest to surges. On the basis of these data, we have assumed that the maximum high-tide level is $30 \mathrm{~cm}$ a.m.s.l. (above mean sea level) and, accordingly, we have changed the local topo-bathymetry of grid 4, that is the one covering Alexandria with the highest resolution $(40 \mathrm{~m})$, and performed tsunami simulations for all the relevant earthquake sources. Following the same analysis procedure used in the paper, we have first assembled the aggregate, then computed the inundation area and made estimates on the affected buildings and people.

Expectedly, the aggregate inundation area increases, passing from 15.6 to $16.4 \mathrm{~km}^{2}$, which in terms of tessellation cells, constructions and persons leads to the respective totals of 2560 (vs. 2433), 13340 (vs. 12398) and 165608 (vs. 153916). There are 942 more buildings that fall in the more extended inundation area, most of which $(72 \%)$ happen to belong to the least vulnerable classes, D and E. Table A1 shows the new building class distribution. The maximum high-tide sea level condition entails a higher water column in all inundated cells. Comparing Table A2 with the analogous Table 6, one sees that the number of cells with water height in the 3-4 m range almost doubles (increasing from 37 to 71 ) and that also cells in the ranges $1-2$ and $2-3 \mathrm{~m}$ increase respectively from 675 to 739 , and from 292 to 356. Likewise, also the damage level to buildings gets higher. From Table A3 where the frequency distribution of buildings' damage level is shown for the mean-sea-level as well as the maximum high-tide level aggregate inundation, one can observe that the highest increment is found for the light damage level D1. It may also be noted that the frequency of buildings with the most severe damage level (D5 = total collapse) increases by a factor larger than 2 (from 5 to 11). Eventually, after applying the same estimation algorithm used in the main text, we are able to pass from the number of affected buildings to the evaluated number of exposed residents portrayed in the last column of Table A2. They are as many as 165608 . Of these, about 109500 live in zones with inundation depth less than $1 \mathrm{~m}$, but about 11000 can be in serious trouble since they reside in lowland areas, where the inundation depth may exceed $2 \mathrm{~m}$. Looking at Table 6, where the corresponding estimates calculated for the mean-sea-level conditions are displayed, one sees that about 108000 people live in areas with less than $1 \mathrm{~m}$ inundation and that about 7000 live where tsunami inundation can be higher than $2 \mathrm{~m}$. It is worth noting that the increment of the number of exposed people is not proportionally distributed among the discrete classes of inundation height, but conversely the number of people living in 
cells with expected higher water level increases (both in percentage and in absolute value) much more than the number of people in low inundation level. 


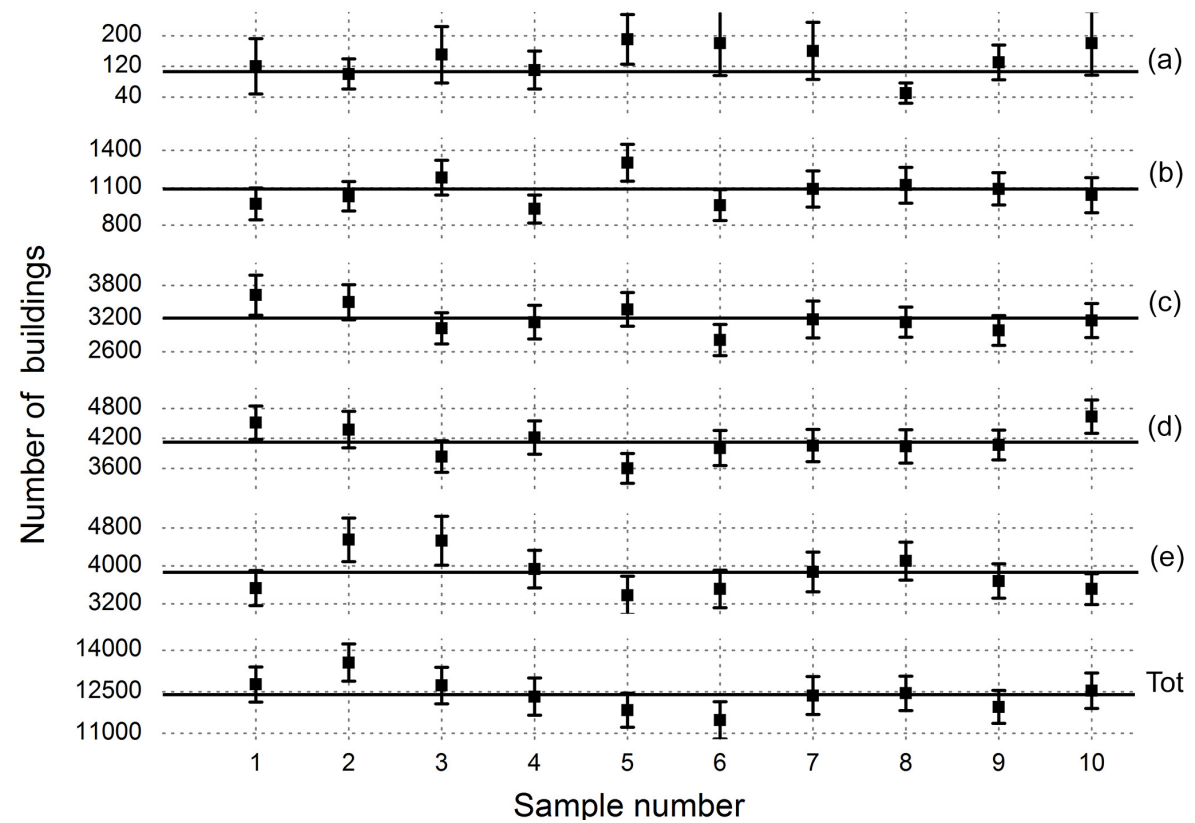

Figure A1. Number of buildings for each building type from A to E and total number of buildings for each of the 10 random, independent samples of cells (each containing 243 cells). The horizontal lines in each subplot correspond to the value reported in Table 5 and refer to the full set of 2433 cells.

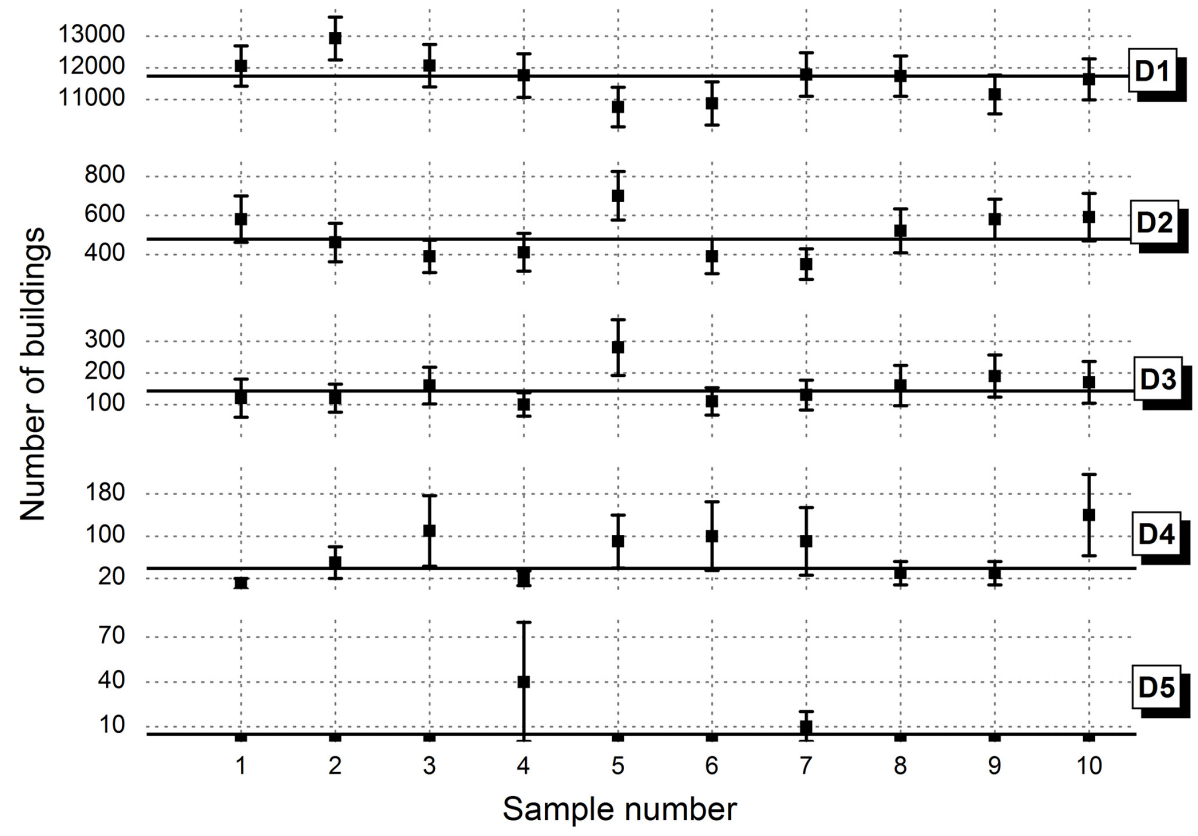

Figure A2. Number of buildings for each damage level from D1 to D5 for each of the 10 random, independent samples of cells (each containing 243 cells). The horizontal lines in each subplot correspond to the value reported in Table 6 (last row) and refer to the full set of 2433 cells. Data refer to the mean-sea-level case. 
Table A1. Vulnerability classification of the buildings inside the aggregate inundation area under the assumption of maximum high-tide. It extends over $16 \mathrm{~km}^{2}$.

\begin{tabular}{lcccccc}
\hline \multicolumn{7}{c}{ Vulnerability classification } \\
\hline Class & A & B & C & D & E & Total \\
\hline No. buildings & 109 & 1156 & 3407 & 4390 & 4278 & 13340 \\
\hline
\end{tabular}

Table A2. Damage to buildings and exposed persons in the case of maximum high-tide conditions.

\begin{tabular}{|c|c|c|c|c|c|c|c|c|c|c|}
\hline \multirow{2}{*}{$\begin{array}{l}\text { Flow } \\
\text { depth } \\
(\mathrm{m})\end{array}$} & \multirow{2}{*}{$\begin{array}{l}\text { No. } \\
\text { cells }\end{array}$} & \multirow{2}{*}{$\begin{array}{l}\text { Area } \\
\left(\mathrm{km}^{2}\right)\end{array}$} & \multirow{2}{*}{$\begin{array}{l}\text { No. } \\
\text { buildings }\end{array}$} & \multicolumn{6}{|c|}{ Number of buildings } & \multirow[t]{2}{*}{ Persons } \\
\hline & & & & D0 & D1 & D2 & D3 & D4 & D5 & \\
\hline $0.0-0.5$ & 700 & 4.48 & 4708 & 0 & 4708 & 0 & 0 & 0 & 0 & 58448 \\
\hline $0.5-1.0$ & 694 & 4.44 & 4106 & 0 & 4093 & 13 & 0 & 0 & 0 & 50974 \\
\hline $1.0-1.5$ & 444 & 2.84 & 2419 & 0 & 2173 & 224 & 22 & 0 & 0 & 30031 \\
\hline $1.5-2.0$ & 295 & 1.89 & 1224 & 0 & 1073 & 131 & 20 & 0 & 0 & 15195 \\
\hline $2.0-2.5$ & 224 & 1.43 & 622 & 0 & 364 & 130 & 97 & 31 & 0 & 7721 \\
\hline $2.5-3.0$ & 132 & 0.84 & 196 & 0 & 93 & 60 & 32 & 11 & 0 & 2433 \\
\hline $3.0-4.0$ & 71 & 0.45 & 65 & 0 & 0 & 47 & 7 & 0 & 11 & 806 \\
\hline Total & 2560 & 16.38 & 13340 & 0 & 12504 & 605 & 178 & 42 & 11 & 165608 \\
\hline
\end{tabular}

Table A3. Number of buildings per level of damage in case of mean sea level (m.s.1.) and of maximum high-tide level (MHL).

\begin{tabular}{lcrrrrr}
\hline Sea level & \multicolumn{6}{c}{ Number of buildings } \\
\cline { 2 - 7 } & D0 & D1 & D2 & D3 & D4 & D5 \\
\hline m.s.l. & 0 & 11732 & 479 & 143 & 39 & 5 \\
MHL & 0 & 12504 & 605 & 178 & 42 & 11 \\
\hline Difference (MHL - m.s.l.) & 0 & 772 & 126 & 35 & 3 & 6 \\
\hline
\end{tabular}


Acknowledgements. The research conducted in this paper is the follow-up of research initiated during the European FP6 project TRANSFER (contract no. 037058) and continued in the framework of the FP6 project SCHEMA (contract no. SST5CT-2006-030963). It is also partially financed by the on-going FP7 project ASTARTE - "Assessment, Strategy And Risk Reduction for Tsunamis in Europe" (FP7-ENV2013 6.4-3, Grant 603839).

Edited by: I. Didenkulova

Reviewed by: P. Dunbar and another anonymous referee

\section{References}

Altinok, Y. and Ersoy, S.: Tsunamis observed on and near the Turkish Coast, Nat. Hazards, 21, 185-205, 2000.

Altinok, Y., Alpar, B., Özer, N., and Aykurt, H.: Revision of the tsunami catalogue affecting Turkish coasts and surrounding regions, Nat. Hazards Earth Syst. Sci., 11, 273-291, doi:10.5194/nhess-11-273-2011, 2011.

Ambraseys, N. N.: Data for the investigation of the seismic seawaves in the Eastern Mediterranean, Bull. Seismol. Soc. Am., 52, 895-913, 1962.

Ambraseys, N. N., Melville, C. P., and Adam, R. D.: The Seismicity of Egypt, Arabia and the Red Sea: A Historical Review, Cambridge University Press, Cambridge, UK, 1994.

Antonopoulos, J. A.: Data from the investigation of seismic seawave events in the eastern Mediterranean from the birth of Christ to $1980 \mathrm{AD}$ (six parts), Ann. Geophys., 33, 141-248, 1980,

http://www.ann-geophys.net/33/141/1980/.

Atillah, A., El Hadani, D., Moudni, H., Lesne, O., Renou, C., Mangin, A., and Rouffi, F.: Tsunami vulnerability and damage assessment in the coastal area of Rabat and Salé, Morocco, Nat. Hazards Earth Syst. Sci., 11, 3397-3414, doi:10.5194/nhess-113397-2011, 2011.

Birkmann, J. and Fernando, N.: Measuring revealed and emergent vulnerabilities of coastal communities to tsunami in Sri Lanka, Disasters, 32, 82-105, 2008.

Brizuela, B., Armigliato, A., and Tinti, S.: Assessment of tsunami hazards for the Central American Pacific coast from southern Mexico to northern Peru, Nat. Hazards Earth Syst. Sci., 14, 1889-1903, doi:10.5194/nhess-14-1889-2014, 2014.

Burbidge, D., Cummins, P. R., Mleczko, R., and Thio, H. A.: Probabilistic tsunami hazard assessment for Western Australia, Pure Appl. Geophys., 165, 2059-2088, 2008.

Camarasa Belmonte, A. M., López-García, M. J., and SorianoGarcía, J.: Mapping temporally-variable exposure to flooding in small Mediterranean basins using land-use indicators, Appl. Geogr., 31, 136-145, 2011.

Cruz, A. M., Krausmann, E., and Franchello, G.: Analysis of tsunami impact scenarios at an oil refinery, Nat. Hazards, 58, 141-162, 2011.

Ebeling, C. W., Okal, E. A., Kalligeris, N., and Synolakis, C. E.: Modern seismological reassessment and tsunami simulation of historical Hellenic Arc earthquakes, Tectonophysics, 530-531, 225-239, 2012

Eckert, S., Jelinek, R., Zeug, G., and Krausmann, E.: Remote sensing-based assessment of tsunami vulnerability and risk in Alexandria, Egypt, Appl. Geogr., 32, 714-723, 2012.
El Alami, S. O. and Tinti, S.: A preliminary evaluation of the tsunami hazards in the Moroccan coasts, Sci. Tsunami Hazards, 9, 31-38, 1991.

El-Geziry, T. M. and Radwan, A.: Sea level analysis off Alexandria, Egypt, Egypt. J. Aquat. Res., 38, 1-5, 2012.

El-Geziry, T. M., Abd Ellah, R. G., and Maiyza, I. A.: Bathymetric Chart of Alexandria Eastern Harbor, Egypt. J. Aquat. Res., 33, 15-21, 2007.

El-Sayed, A., Romanelli, F., and Panza, G.: Recent seismicity and realistic waveforms modeling to reduce the ambiguities about the 1303 seismic activity in Egypt, Tectonophysics, 328, 341-357, 2000.

Fokaefs, A. and Papadopoulos, G. A.: Tsunami hazard in the Eastern Mediterranean: strong earthquakes and tsunamis in Cyprus and the Levantine Sea, Nat. Hazards, 40, 503-526, 2007.

Fritz, H. M., Phillips, D. A., Okayasu, A., Shimozono, T., Liu, H. J., Mohammed, F., Skanavis, V., Synolakis, C. E., and Takahashi, T.: The 2011 Japan tsunami current velocity measurements from survivor videos at Kesennuma Bay using LiDAR, Geophys. Res. Lett., 39, L00G23, doi:10.1029/2011GL050686, 2012.

Gardi, A., Valencia, N., Guillande, R., and André, C.: Inventory of uncertainties associated with the process of tsunami damage assessment on buildings (SCHEMA FP6 EC co-funded project), Nat. Hazards Earth Syst. Sci., 11, 883-893, doi:10.5194/nhess11-883-2011, 2011.

Garziglia, S., Ioualalen, M., Migeon, S., Ducassou, E., Mascle, J., Sardou, O., and Brosolo, L.: Triggering Factors and Tsunamigenic Potential of a Large Submarine Mass Failure on the Western Nile Margin (Rosetta Area, Egypt), in: Submarine Mass Movements and Their Consequences - Advances in Natural and Technological Hazards Research, edited by: Lykousis, V., Sakellariou, D., and Locat, J., Springer, Dordrecht, the Netherlands, 347-355, 2007.

Geist, E. L. and Parsons, T.: Probabilistic analysis of tsunami hazards, Nat. Hazards, 37, 277-314, 2006.

Gonzalez, F. I., Geist, E. L., Jaffe, B., Kanoglu, U., Mofjeld, H., Synolakis, C. E., Titov, V. V., Arcas, D., Bellomo, D., Carlton, D., Horning, T., Johnson, J., Newman, J., Parsons, T., Peters, R., Peterson, C., Priest, G., Venturato, A., Weber, J., Wong, F., and Yalciner, A.: Probabilistic tsunami hazard assessment at Seaside, Oregon, for near- and far-field seismic sources, J. Geophys. Res., 114, C11023, doi:10.1029/2008JC005132, 2009.

Grilli, S. T., Taylor, O. D. S., Baxter, C. D. P., and Maretzki, S.: Probabilistic approach for determining submarine landslide tsunami hazard along the upper East Coast of the United States, Mar. Geol., 264, 74-97, 2009.

Grilli, S. T., Harris, J., and Tajalli Bakhsh, T.: Literature Review of Tsunami Sources Affecting Tsunami Hazard Along the US East Coast, NTHMP Progress report, Res. Rept. CACR-11-08, Center for Applied Coastal Research, University of Delaware, Newark, 2011.

Guidoboni, E. and Comastri, A.: The large earthquake of 8 August 1303 in Crete: seismic scenario and tsunami in the Mediterranean area, J. Seismol., 1, 55-72, 1997.

Guidoboni, E. and Comastri, A.: Catalogue of Earthquakes and Tsunamis in the Mediterranean area from the 11th to the 15th Century, INGV-SGA, Bologna, 2005. 
Guidoboni, E., Comastri, A., and Traina, G.: Catalogue of Ancient Earthquakes in the Mediterranean Area up to 10th Century, Istituto Nazionale di Geofisica, Roma, 1994.

Koshimura, S., Namegaya, Y., and Yanagisawa, H.: Tsunami Fragility: a new measure to assess tsunami damage, J. Disaster Res., 4, 479-488, 2009a.

Koshimura, S., Oie, T., Yanagisawa, H., and Imamura, F.: Developing fragility curves for tsunami damage estimation using numerical model and post-tsunami data from Banda Aceh, Indonesia, Coast Eng. J., 51, 243-273, 2009b.

Leonard, L. J., Rogers, G. C., and Mazzotti, S.: Tsunami hazard assessment of Canada, Nat. Hazards, 70, 237-274, 2014.

Leone, F., Lavigne, F., Paris, R., Denain, J. C., and Vinet, F.: A spatial analysis of the December 26th, 2004 tsunami-induced damages: lessons learned for a better risk assessment integrating buildings vulnerability, Appl. Geogr., 31, 363-375, 2011.

Lin, I. C. and Tung, C. C.: A preliminary investigation of tsunami hazard, Bull. Seismol. Soc. Am., 72, 2323-2337, 1982.

Lorito, S., Selva, J., Basili, R., Romano, F., Tiberti, M. M., and Piatanesi, A.: Probabilistic Hazard for Seismically-Induced Tsunamis: Accuracy and Feasibility of Inundation Maps, Geophys. J. Int., 200, 574-588, 2015.

Lorito, S., Tiberti, M. M., Basili, R., Piatanesi, A., and Valensise, G.: Earthquake-generated tsunamis in the Mediterranean Sea: Scenarios of potential threats to Southern Italy, J. Geophys. Res., 113, B01301, doi:10.1029/2007JB004943, 2008.

Okada, Y.: Internal deformation due to shear and tensile faults in a half-space, Bull. Seismol. Soc. Am., 82, 1018-1040, 1992.

Pagnoni, G., Tinti, S., and Rallo, F.: Application and comparison of tsunami vulnerability models in the gulf of Siracusa, Sicily, EGU General Assembly, 27 April-2 May 2014, Vienna, Austria, EGU2014-10621, 2014.

Papadopoulos, G. A.: A Seismic History of Crete: Earthquakes and Tsunamis, 2000 B.C.-A.D. 2010, Ocelotos Publications, Athens, 2011.

Papadopoulos, G. A., Daskalaki, E., Fokaefs, A., and Giraleas, N.: Tsunami hazards in the Eastern Mediterranean: strong earthquakes and tsunamis in the East Hellenic Arc and Trench system, Nat. Hazards Earth Syst. Sci., 7, 57-64, doi:10.5194/nhess-7-572007, 2007.

Papadopoulos, G. A., Gràcia, E., Urgeles, R., Sallares, V., De Martini, P. M., Pantosti, D., González, M., Yalciner, A., Mascle, J., Sakellariou, D., Salamon, A., Tinti, S., Karastathis, V., Fokaefs, A., Camerlenghi, A., Novikova, T., and Papageorgiou, A.: Historic and pre-historic tsunamis in the Mediterranean and its connected seas: documentation, geological signatures, generation mechanisms and coastal impacts, Mar. Geol., 354, 81-109, 2014.

Pararas-Carayannis, G.: The Earthquake and Tsunami of July 21, 365 in the Eastern Mediterranean Sea - Review of Impact on the Ancient World - Assessment of Recurrence and Future Impact, Sci. Tsunami Hazards, 30, 253-292, 2011.

Pirazzoli, P. A., Ausseil-Badie, J., Giresse, P., Hadjidaki, E., and Arnold, M.: Historical environmental changes at Phalasarna harbor, West Crete, Geoarchaeology, 7, 371-392, 1992.

Pirazzoli, P. A., Laborel, J., and Stiros, S. C.: Earthquake clustering in the eastern Mediterranean during historical times, J. Geophys. Res., 101, 6083-6097, 1996.

Reese, S., Cousins, W. J., Power, W. L., Palmer, N. G., Tejakusuma, I. G., and Nugrahadi, S.: Tsunami vulnerability of buildings and people in South Java - field observations after the July 2006 Java tsunami, Nat. Hazards Earth Syst. Sci., 7, 573589, doi:10.5194/nhess-7-573-2007, 2007.

Ribeiro, J., Silva, A., and Leitão, P.: High resolution tsunami modelling for the evaluation of potential risk areas in Setúbal (Portugal), Nat. Hazards Earth Syst. Sci., 11, 2371-2380, doi:10.5194/nhess-11-2371-2011, 2011.

Ruangrassamee, A., Yanagisawa, H., Foytong, P., Lukkunaprasit, P., Koshimura, S., and Imamura, F.: Investigation of Tsunamiinduced damage and fragility of buildings in Thailand after the December 2004 Indian Ocean Tsunami, Earthq. Spectra, 22, 377-401, 2006.

Salamon, A., Rockwell, T., Ward, S. N., Guidoboni, E., and Comastri, A.: Tsunami Hazard Evaluation of the Eastern Mediterranean: Historical Analysis and Selected Modeling, Bull. Seismol. Soc. Am., 97, 705-724, doi:10.1785/0120060147, 2007.

Shaw, B., Ambraseys, N. N., England, P. C., Floyd, M. A., Gorman, G. J., Higham, T. F. G., Jackson, J. A., Nocquet, J. M., Pain, C. C., and Piggott, M. D.: Eastern Mediterranean tectonics and tsunami hazard inferred from the AD 365 earthquake, Nat Geosci., 1, 268-276, 2008.

Soloviev, S. L., Solovieva, O. N., Go, C. N., Kim, K. S., and Shchetnikov, N. A.: Tsunamis in the Mediterranean Sea 2000 B.C.2000 A.D., in: Advances in natural and technological hazards research, 13, Kluwer Academic Publisher, Dordrecht, 2000.

Sørensen, M. B., Spada, M., Babeyko, A., Wiemer, S., and Grünthal, G.: Probabilistic tsunami hazard in the Mediterranean Sea, J. Geophys. Res., 117, B01305, doi:10.1029/2010JB008169, 2012.

Stiros, S. C.: The AD 365 Crete earthquake and possible seismic clustering during the 4-6th centuries AD in the Eastern Mediterranean: a review of historical and archaeological data, J. Struct. Geol., 23, 545-562, 2001.

Stiros, S. C.: The 8.5+magnitude, AD 365 earthquake in Crete: Coastal uplift, topography changes, archaeological and historical signature, Quatern. Int., 216, 54-63, doi:10.1016/j.quaint.2009.05.005, 2010.

Suppasri, A., Mas, E., Charvet, I., Gunasekera, R., Imai, K., Fukutani, Y., Abe, Y., and Imamura, F.: Building damage characteristics based on surveyed data and fragility curves of the 2011 Great East Japan tsunami, Nat. Hazards, 66, 319-341, 2013.

Tinti, S.: Assessment of tsunami hazard in the Italian Seas, Nat. Hazards, 4, 267-283, 1991a.

Tinti, S.: Tsunami potential in Southern Italy, Sci. Tsunami Hazards, 9, 5-14, 1991b.

Tinti, S. and Tonini, R.: The UBO-TSUFD tsunami inundation model: validation and application to a tsunami case study focused on the city of Catania, Italy, Nat. Hazards Earth Syst. Sci., 13, 1795-1816, doi:10.5194/nhess-13-1795-2013, 2013.

Tinti, S., Armigliato, A., Pagnoni, G., and Zaniboni, F.: Scenarios of giant tsunamis of tectonic origin in the Mediterranean, ISET J. Earthq. Tech., 42, 171-188, 2005.

Tonini, R., Armigliato, A., Pagnoni, G., Zaniboni, F., and Tinti, S.: Tsunami hazard for the city of Catania, eastern Sicily, Italy, assessed by means of Worst-case Credible Tsunami Scenario Analysis (WCTSA), Nat. Hazards Earth Syst. Sci., 11, 1217-1232, doi:10.5194/nhess-11-1217-2011, 2011. 
Valencia, N., Gardi, A., Gauraz, A., Leone, F., and Guillande, R.: New tsunami damage functions developed in the framework of SCHEMA project: application to EuropeanMediterranean coasts, Nat. Hazards Earth Syst. Sci., 11, 28352846, doi:10.5194/nhess-11-2835-2011, 2011.
Yolsal-Çevikbilen, S. and Taymaz, T.: Earthquake source parameters along the Hellenic subduction zone and numerical simulations of historical tsunamis in the Eastern Mediterranean, Tectonophysics, 536-537, 61-100, 2012. 